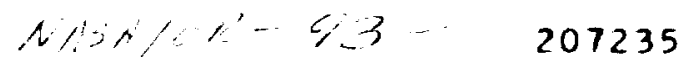

Geochimica el Cosmochimica Acta vol. 57, pp. 4813-4826

Copyright 6 1993 Pergamon Press Ltd. Printed in U.S.A.

$0016.7037 / 93 / \$ 6.00+.00$

\title{
Composition and maturity of Apollo 16 regolith core 60013/14
}

\author{
RANDY L. KOROTEV ' and RICHARD V. MORRIS ${ }^{2}$ \\ 'Department of Earth and Planetary Sciences and McDonnell Center for the Space Sciences. Washington University, \\ St. Louis, MO 63130. USA \\ ${ }^{2}$ Code SN4, NASA Johnson Space Center, Houston, TX 77058, USA
}

(Received April 2, 1993; accepted in revised form July' 26, 1993)

\begin{abstract}
Samples from every half-centimeter dissection interval of double drive tube $60013 / 14$ (sections 60013 and 60014) were analyzed by magnetic techniques for $\mathrm{Fe}^{\circ}$ concentration and surface maturity parameter $I_{s} / \mathrm{FeO}$, and by neutron activation for concentrations of 25 lithophile and siderophile elements. Core $60013 / 14$ is one of three regolith cores taken in a triangular array $40-50 \mathrm{~m}$ apart on the Cayley plains during Apollo 16 mission to the Moon. The core can be divided into three zones based both on $I_{s} / \mathrm{FeO}$ and composition. Unit $\mathrm{A}(0-44 \mathrm{~cm}$ depth) is compositionally similar to other soils from the surface of the central region of the site and is mature throughout, although maturity decreases with depth. Unit B $(44-59 \mathrm{~cm})$ is submature and compositionally more feldspathic than Unit A. Regions of lowest maturity in Unit B are characterized by lower $\mathrm{Sm} / \mathrm{Sc}$ ratios than any soil obtained from the Cayley plains as a result of some unidentified lithologic component with low surface maturity. The component is probably some type of mafic anorthosite that does not occur in such high abundance in any of the other returned soils. Unit $C(59-62 \mathrm{~cm})$ is more mature than Unit B and compositionally equivalent to an 87: 13 mixture of soil such as that from Unit A and plagioclase such as found in ferroan anorthosite. Similar soils, but containing greater abundances of anorthosite (plagioclase), are found at depth in the other two cores of the array. These units of immature to submature soil enriched to varying degrees (compared to the mature surface soil) in ferroan anorthosite consisting of $\sim 99 \%$ plagioclase are the only compositionally distinct subsurface similarities among the three cores. Each of the cores contains other units that are compositionally dissimilar to any soil unit in the other two cores. These compositionally distinct units probably derive from local subsurface blocks deposited by the event $(s)$ that formed the Cayley plains. The ferroan anorthosite with $\sim 99 \%$ plagioclase, however, must represent some subsurface lithology that is significant on the scale of tens of meters. The compositional uniformity of the surface soil $(0-10 \mathrm{~cm}$ depth) over distances of kilometers reflects the large-scale uniformity of the plains deposits; the finestructure reflects small-scale nonuniformity and the inefficiency of the impact-mixing process at depths as shallow as even one meter.
\end{abstract}

\section{INTRODUCTION}

THE MOON, asteroids, and those terrestrial planets with minor atmospheres are covered with regoliths produced by countless impacts of meteoroids with the surfaces. These regoliths obscure bedrock from access by both sample-return missions and remote sensing. For the Moon, virtually all of our samples are from the regolith and nearly all spectral data obtained remotely from orbit or Earth-based telescopes is for regolith occurring only at the very surface. As a result, most of what we know about the Moon derives from the regolith (MC KAY et al., 1991). This situation is, or for future missions is likely to be, largely true for Mars and asteroids as well. Thus, an understanding of regolith formation processes is essential to interpretation of both sample and remotely sensed data.

Because the Moon is airless and large, the lunar regolith is thick, on the order of 5-15 m. Most information on its nature at depth is based on seismic data, cores taken by Apollo astronauts, and photographs of craters, rille walls, and shallow trenches. The cores have shown that the regolith is highly layered with respect to grain size, color, composition, modal petrography, and other parameters. Although these one-dimensional probes reveal little of the 3-dimensional structure of the regolith, we can infer that lunar stratigraphy resulting from overlapping ejecta deposits of countless impact craters differs substantially from terrestrial sedimentary stratigraphy. (See MCKAY et al. ( 1991 ) for a review of current knowledge of the lunar regolith.)

The $60013 / 14$ double drive tube (sections 60013 and $60014,62 \mathrm{~cm}$ deep) is one of three regolith cores taken 40 $50 \mathrm{~m}$ apart in a triangular array on the Cayley plains at station 10 southwest of the LM (lunar module) on the Apollo 16 mission to the Central Highlands (Figs. 1 and 2). This trio, which includes double drive tube $60009 / 10$ (59 $\mathrm{cm}$ deep) and drill core $6000 \mathrm{l}-7$ (220 cm deep), is the only such array of cores returned from the Moon and, thus, is the only set of samples in which stratigraphically continuous layers of regolith might be sought. In this work we compare new data for surface maturity and composition in recently opened core $60013 / 14$ with similar data for previously studied cores 60009/10 and 60001-7 (MORRIS and GOSE, 1976; MC KAY et al., 1976; 1977; GOSE and MORRIS, 1977; KOROTEV, 1991) in order to seek stratigraphic correlations among the cores and understand what the cores reveal about regolith formation and Apollo 16 site geology.

\section{SAMPLES AND METHODS}

As in our previous joint core studies, we obtained ferromagnetic resonance (FMR), magnetic, and instrumental neutron activation analysis (INAA) data on 50-mg (nominal) samples of $<1 \mathrm{~mm}$ fines 


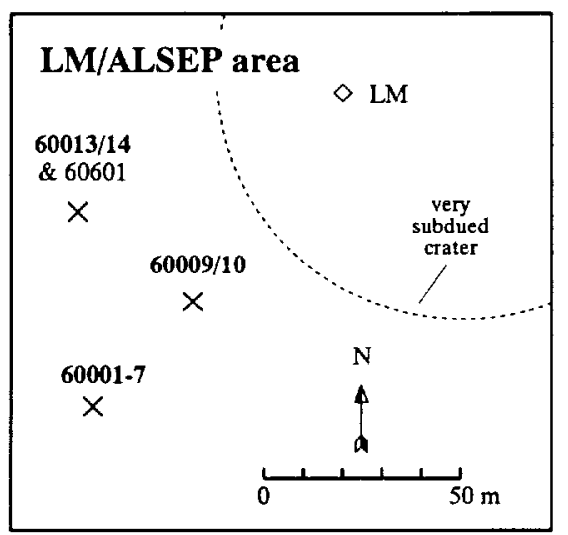

FIG. 1. Schematic map of the LM/ALSEP area ( station 10) of the Apollo 16 landing site, indicating the relative positions of the three cores discussed in this work (based on Fig. 1 of SCHABER, 1981).

from each half-centimeter dissection interval of the core (KOROTEV et al., 1984: MORRIS et al.. 1989). These 124 samples are from the first dissection pass of both core tube sections (SCHWARZ, 1991, 1992). Neutron irradiation for INAA occurred after the magnetic studies. and data for twenty five elements were obtained. The FMR intensity, $l_{s}$, divided by the concentration of $\mathrm{FeO}$ ( total Fe expressed as percent $\mathrm{FeO}$ ) determined by INAA defines the surface maturity parameter $I_{s} / \mathrm{FeO}$ (MORRIS, 1976). Analytical methods are described in previous papers (FMR and magnetic: MORRIS, 1976; MORRIS and GOSE, 1976; and MORRIS et al., 1978, 1979; INAA: KOROTEV, 1991.

As is customary for lunar samples, saturation magnetizations are assumed to result entirely from metallic iron and are reported as weight percent $\mathrm{Fe}^{\circ}$ by dividing the value measured for the sample by that for pure metallic iron; the measurement uncertainty is about $\pm 0.02 \mathrm{wt} \%$. The saturation magnetization (at room temperature) of Fe-Ni alloys having $0-15 \mathrm{wt} \% \mathrm{Ni}$ are within $5 \%$ of the value for pure metallic iron (e.g., BOZARTH, 1951); if alloys having $>15$ wt $\%$ Ni are present, then the actual concentration of metal alloy present is larger than reported values of $\mathrm{Fe}^{\circ}$. However, most metal in Apollo 16 soils has $<8$ wt $\%$ Ni (below). Consequently, our reported $\mathrm{Fe}^{\circ}$ concentrations are essentially equivalent to the total metal concentration, i.e., fine-grained, single domain Fe from soil maturation processes plus coarser-grained $\mathrm{Fe}-\mathrm{Ni}$ alloys from meteorites (MORRIS, 1978b; MORRIS et al., 1989).

Results of INAA indicate that some samples contain anomalously high concentrations of gold compared to nickel and iridium, presumably as a result of contamination from some unknown source. The four samples between 12.0 and $14.0 \mathrm{~cm}$ depth, the four samples between 24.5 and $26.5 \mathrm{~cm}$ depth, and the bottom sample in each core section $(28.0-28.2$ and $61.7-61.9 \mathrm{~cm})$ have chondrite-normalized $\mathrm{Au} / \mathrm{Ni}$ ratios ranging from 3.7 to 47 , compared to $1.47 \pm 0.24$ (mean \pm standard deviation) for other samples in the core. Also, one sample (60013.171 from parent split 48 at $37.2-37.7 \mathrm{~cm}$ depth) is anomalous in containing high concentrations of ITEs (incompatible trace elements. presumably from a large fragment of ITE-rich melt breccia) and another (60013, 164 from parent split 36 at $34.2-34.7 \mathrm{~cm}$ depth) has exceptionally high concentrations of all siderophile elements (from a large metal grain, see below). We obtained twelve additional splits each $\sim 120 \mathrm{mg}$ in mass from the dissection intervals in which most of the anomalous samples had been obtained: ten of these were from the vicinity of the two 2-cm-wide zones of stratigraphically adjacent samples with $\mathrm{Au}$ contamination. These twelve splits were each divided into two $60-\mathrm{mg}$ samples and analyzed by neutron activation, for a total of twenty four additional analyses. The analyses indicate that none of the replicate splits are contaminated with Au or otherwise anomalous. We do not know the cause of the gold contamination in the original samples as they were handled and analyzed in random order with respect to stratigraphy in both analytical laboratories. In the figures, 2-element plots include points for all 148 samples analyzed by INAA, whereas depth profiles include only data for the original
124 samples. except that we disregard the ITE-rich sample $(600 / 3$, $171)$ as a sampling anomaly and plot instead the mean of the two nonanomalous splits. We also present new INAA data for samples from every half-centimeter dissection interval of 64002 , the upper half of the double drive tube at station 4 (Fig. 2), and for regolith samples from station 11 at North Ray crater. The latter include samples 67011, 67020,67031, 67410,67450,67610; most of these are atypical and previously unstudied fines each derived primarily from a single, friable rock.

\section{RESULTS}

\section{Surface Exposure (Maturity)}

Soil in the core is submature to mature, with $I_{s}$ /FeO ranging between 35 and 110 units (Fig. 3a). (See MORRIS, 1976, $1978 \mathrm{~b}$ for a discussion of $l_{s} / \mathrm{FeO}$ and other surface exposure (maturity) indices.) The most mature soil is at the top and maturity decreases gradually with depth to about $44 \mathrm{~cm}$; an exception is the top $3 \mathrm{~cm}$ of soil, which is somewhat less mature $\left(I_{s} / \mathrm{FeO}=90 \pm 2\right)$ than the $7 \mathrm{~cm}$ of soil immediately below it $\left(I_{s} / \mathrm{FeO}=102 \pm 4\right)$. Between a depth of 44 and 46 $\mathrm{cm}$ maturity drops abruptly. We will refer to the mature soil between the surface and $44 \mathrm{~cm}$ depth as Unit A. All soil below $45 \mathrm{~cm}$ depth is submature. The inflection at $45 \pm 1$ $\mathrm{cm}$ is the most prominent feature in the maturity profile of the core and corresponds to the dark/light contact observed during core processing (SCHWARZ, 1992), with the submature, deeper soil being lighter in color. As shown below, the composition also becomes more feldspathic below the dark/

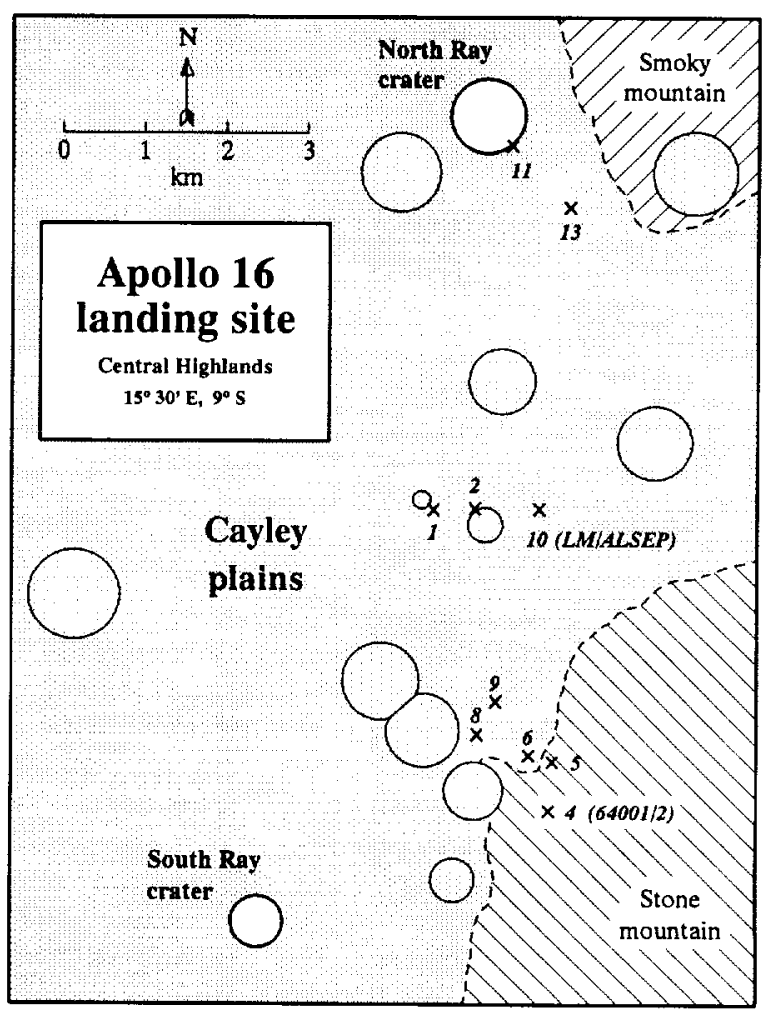

FIG. 2. Schematic map of the Apollo 16 landing site, showing location of sampling stations (based on Fig. 5 of MUEHLBERGtR. 1981). 

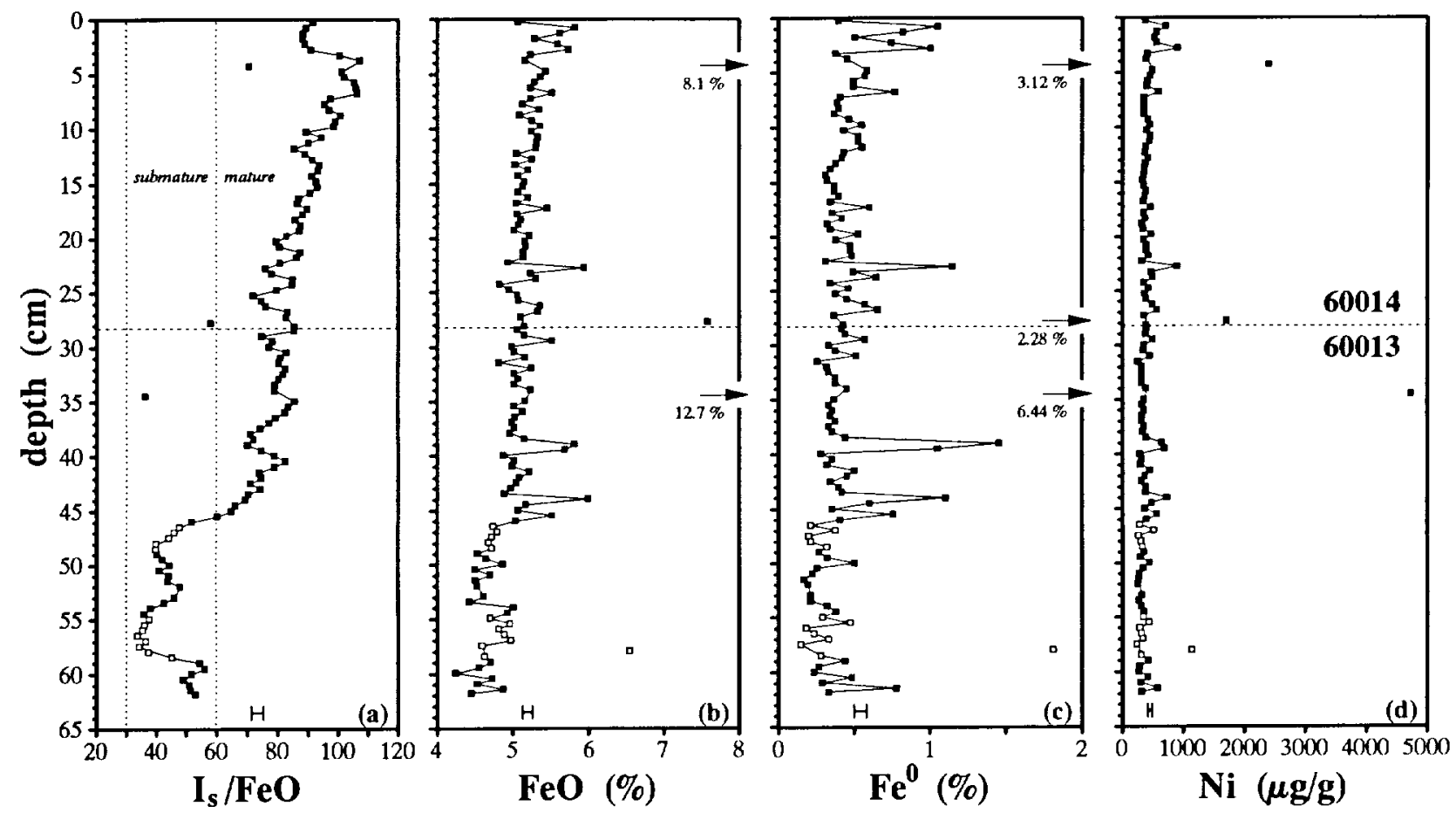

Fig. 3. Depth profiles for $I_{s} / \mathrm{FeO}, \mathrm{FeO}$ (total $\mathrm{Fe}$ as $\mathrm{FeO}$ ), $\mathrm{Fe}^{0}$, and $\mathrm{Ni}$ in $60013 / 14$. The horizontal dashed line represents the break between the two core sections. In a), the data have been smoothed by a three-point running average: vertical dotted lines represents the division between submature and mature soils (MOR R1S, 1976, 1978). The low-Sm/Sc soils (open symbols; see Fig. 5) approach immaturity $\left(I_{s} / \mathrm{FeO}<30\right)$. The error bars at $\sim 6.3 \mathrm{~cm}$ depth represent 2- $\sigma$ analytical uncertainties.

light contact. Although differences in shade resulting from composition (change in the mafic to feldspathic mineral ratio) occur in 60009/10 (MORRIS and GOSE, 1976), the shade change in $60013 / 14$ results primarily from the difference in maturity as the change in composition is minor. A similar shade difference resulting from a change in maturity occurs in section 60002 of the deep drill core (GOSE and MORRIS, 1977). The region of lowest maturity in $60013 / 14\left(34<I_{s} /\right.$ $\mathrm{FeO}<48$ ) extends from 46 to $58 \mathrm{~cm}$ depth. From 58 to 59 $\mathrm{cm}$ the maturity increases and between $59 \mathrm{~cm}$ and the bottom of the core at $62 \mathrm{~cm}$, a region we designate Unit $C$, maturity is relatively constant $\left(I_{s} / \mathrm{FeO}=53 \pm 2\right)$. We will refer to the region between Units $A$ and $C$ as Unit B ( 44 to $59 \mathrm{~cm}$ depth, i.e., the transition zones are assigned to Unit $B)$. Unit $C$ is somewhat darker than Unit B (SCHWARZ, 1992), although astronaut Charles Duke noted that the material at the bottom of the core was whitish and coarse grained when compared to material at the surface (SUTTON, 1980).

\section{Composition}

Concentrations of the twenty-five mostly-trace elements determined here indicate that, to a first approximation, soil samples from core $60013 / 14$ are all very similar in composition to each other and to other soils collected at the central stations ( stations 1,2, and 10). Thus, most of the discussion below involves small differences in concentrations and ratios that result from minor variations with depth in the abundance of various lithologic components of the soil. The similarities in trace-element abundances between $60013 / 14$ samples and surface soils for which major element abundances are well characterized (KOROTEV, 1981) allow us to predict with some confidence, for example, that $\mathrm{Al}_{2} \mathrm{O}_{3}$ concentrations in the $60013 / 14$ soils range from about $26 \%$ to $28 \%$, which corresponds to about $73-79 \%$ normative plagioclase. Because plagioclase abundances are so high, relative differences in composition between different units of soil are demonstrated best by elements associated with the nonplagioclase phases (mainly pyroxene) than by $\mathrm{Al}$ or $\mathrm{Ca}$. Among elements determined here, Sc is particularly useful for this purpose (KOROTEV, 1991).

The three units established on the basis of maturity are each compositionally distinct. In Unit A, i.e., the mature section from the surface to about $44 \mathrm{~cm}$ depth, there is no systematic compositional variation with depth, no unambiguous structure, and little compositional variation of any kind among lithophile elements (Fig. 4). For example, the relative standard deviation in Sc concentrations in the eighty-eight samples of Unit A is only $2.3 \%$ (Table 1 ). The average composition of Unit $A$ is similar to that of surface reference soil 60601 (Fig. 5), which is also mature. Below Unit $A$ the soil becomes more feldspathic, i.e.. there is a general decrease in concentrations of elements associated with mafic phases ( $\mathrm{Sc}$. $\mathrm{Cr}, \mathrm{Fe}$ ) and ITEs (e.g., Sm). Correspondingly, concentrations of $\mathrm{Ca}$, the only element determined here that correlates positively with plagioclase abundance, average $2 \%$ greater in the soils of Units B and C than in Unit A (not shown).

Although both $S c$ and $S m$ concentrations are lower in Unit 

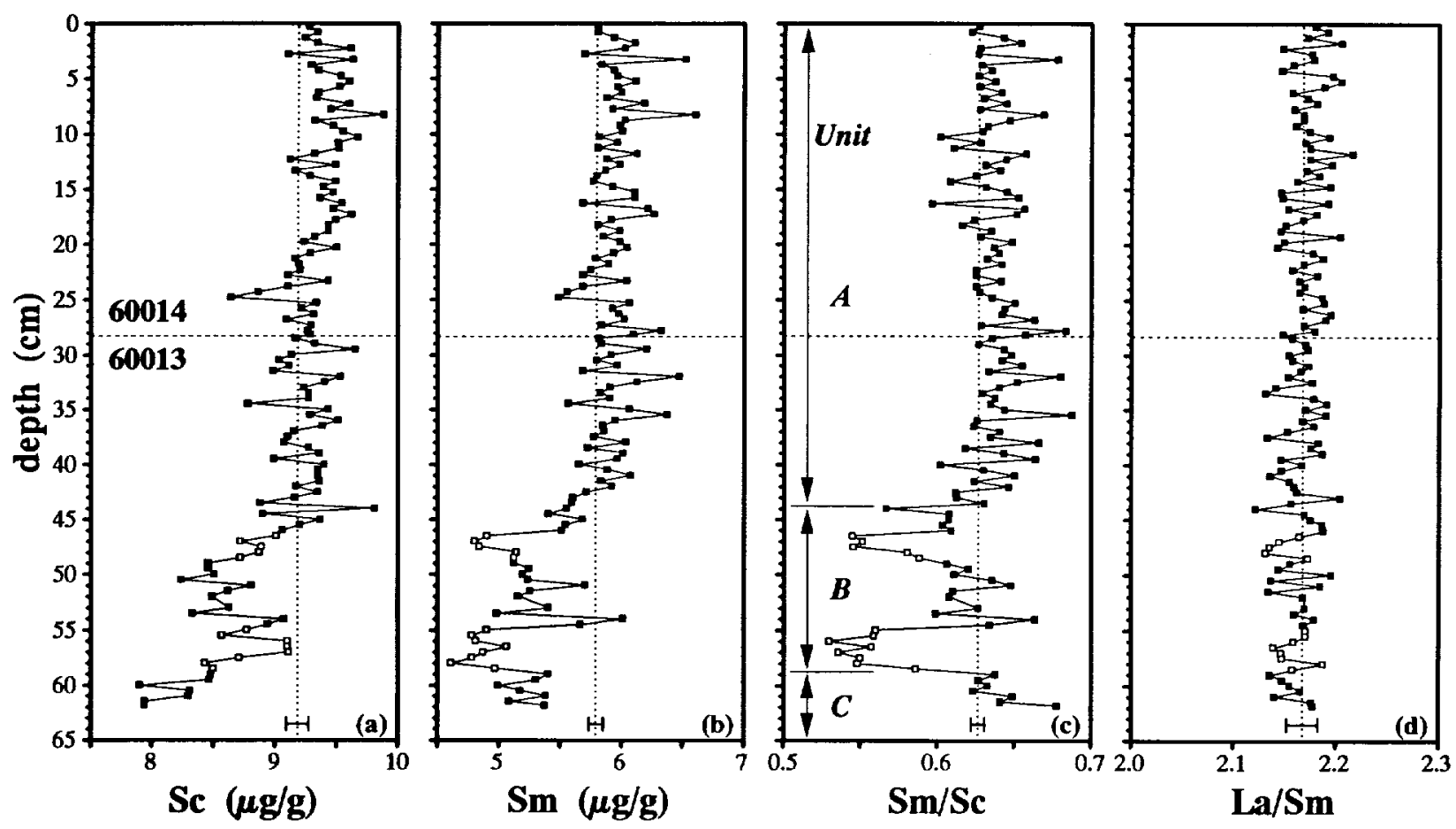

Fig. 4. Depth profiles for Sc, Sm, Sm/Sc, and La/Sm in 60013/14 (see Fig. 3). The vertical dotted lines are for reference and represent the mean concentration or ratio for the core. The limits of stratigraphic Units $A, B$, and $C$ are indicated in $\mathrm{c}$ ). The open squares represent regions of low $\mathrm{Sm} / \mathrm{Sc}$ ratio in Unit B.

B than Unit A, many of the Unit B samples have $\mathrm{Sm} / \mathrm{Sc}$ ratios distinctly less than those of Unit A (Fig. 4). Two bands of low-Sm/Sc soil occur in Unit B, one at $47-49 \mathrm{~cm}$ and the other at $55-58 \mathrm{~cm}$ depth (symbolized by hollow squares in the figures). The two bands of low-Sm/Sc ratio correspond to minima in the $I_{s} / \mathrm{FeO}$ profiles (Fig. 3 ).

In Unit $\mathrm{C}, \mathrm{Sm} / \mathrm{Sc}$ ratios return to the higher values characteristic of Unit $\mathrm{A}$, but absolute $\mathrm{Sc}$ concentrations are the lowest observed in the core. Concentrations of Sc and Sm in the seven samples of unit $C$ average $88 \%$ of the mean concentrations in Unit A. As noted below, this occurs because Unit $C$ is compositionally equivalent to a mixture of Unit A-like soil ( $87 \%$ ) and plagioclase (13\%). Mean concentrations of elements in the three stratigraphic units and in the two bands of low-Sm/Sc soil in Unit B are given in Table 1.

Because mean grain size correlates inversely with $I_{s} / \mathrm{FeO}$ (MORRIS, 1976) and specific area $\left(\mathrm{cm}^{2} / \mathrm{g}\right.$ ) correlates inversely with radius, mass concentrations (e.g., $\mu \mathrm{g} / \mathrm{g}$ ) of surface-correlated elements correlate with $I_{s} / \mathrm{FeO}$. This is roughly what is observed for $\mathrm{Zn}$, suggesting that most of the $\mathrm{Zn}$ in 60013 / 14 is surface-correlated (Fig. 6). Extrapolation of the trend to $I_{s} / \mathrm{FeO}=0$ leads to $5 \mu \mathrm{g} / \mathrm{g} \mathrm{Zn}$, which is typical of the concentrations observed in Apollo 16 rocks. The source of the surface-correlated $\mathrm{Zn}$ in the lunar regolith is not well understood (HASKIN and WARREN, 1991).

\section{DISCUSSION}

\section{Causes of Compositional Variation}

The range of compositional variation in $60013 / 14$ (e.g., 8 to $9.5 \mu \mathrm{g} / \mathrm{g} \mathrm{Sc}$ ) is less than observed in 60006 and 60007 , the top two sections of the deep drill core, and much less than observed in the other double drive tube, $60009 / 10$ (Fig. 7). Core $60009 / 10$ shows more compositional variation with depth than any lunar core yet sampled. Most of the compositional variation in $60009 / 10$ is consistent with variation in the proportions of two components, (1) a soil with 9-10 $\mu \mathrm{g} / \mathrm{g} \mathrm{Sc}$ such as that found at the top of all three cores, and (2) ferroan anorthosite consisting almost entirely ( $\sim 99 \%)$ of plagioclase (MCKAY et al., 1976, 1977; KOROTEV, 1991). (Ferroan anorthosite is the name for the common form of lunar plutonic anorthosite in which mafic minerals have relatively low molar $\mathrm{Mg} /(\mathrm{Mg}+\mathrm{Fe})$ ratios $(0.5-0.7)$ despite high ( An $\sim 96$ ) anorthite content of the plagioclase; see WARREN, 1990.) Because the anorthosite component is virtually pure plagioclase, and thus has very low concentrations of Sc and $\mathrm{Sm}$, and because the variation in its modal abundance is large, concentrations of the two elements are highly correlated among different samples of core soil. Consequently, on most two-element plots, such as the Sc-Sm plot of Fig. $8 \mathrm{~b}, 60009 / 10$ samples define a mixing line. Most soils from the central and southern stations plot along the mixing line defined by the $60009 / 10$ soils, although variation in the proportions of subcomponents of the soil component cause some deviations from the line (KOROTEV, 1991).

Soils from North Ray crater at the northern portion of the site (Fig. 2) do not plot on the 60009/10 mixing trend (Fig. $5 \mathrm{a})$ as these are composed primarily of noritic anorthosite in the form of feldspathic fragmental breccias excavated from the crater. The fragmental breccias are variable in composition. On a lateral scale of tens of meters, fines derived from these different breccias are also variable in composition and 
Table 1. Mean concentrations and $I_{s} / \mathrm{FeO}$ for stratigraphic units from double drive tube $60013 / 14$

\begin{tabular}{|c|c|c|c|c|c|c|}
\hline depth: & $\mathrm{cm}$ & $\begin{array}{c}\text { Unit A } \\
\text { S.D.* } \\
(\mathrm{n}=88)\end{array}$ & $\begin{array}{r}\text { Unit A } \\
0-43.7\end{array}$ & $\begin{array}{c}\text { Unit B } \\
\text { all } \\
43.7-58.7\end{array}$ & $\begin{array}{c}\text { Unit B } \\
\mathrm{lo}-\mathrm{Sm} / \mathrm{Sc} \\
46.2-48.7 \\
54.7-58.7\end{array}$ & $\begin{array}{l}\text { Unit C } \\
58.7-62.0\end{array}$ \\
\hline $\mathrm{Na}_{2} \mathrm{O}$ & $\%$ & 0.007 & 0.453 & 0.432 & 0.422 & 0.440 \\
\hline $\mathrm{CaO}$ & $\%$ & 0.3 & 15.2 & 15.5 & 15.6 & 15.6 \\
\hline Sc & $\mu \mathrm{g} / \mathrm{g}$ & 0.22 & 9.32 & 8.81 & 8.81 & 8.19 \\
\hline $\mathrm{C}_{r}$ & $\mu \mathrm{g} / \mathrm{g}$ & 17 & 762 & 723 & 713 & 670 \\
\hline $\mathrm{Fe}^{0}$ & $\%$ & $(0.02)$ & 0.77 & 0.58 & 0.58 & 0.60 \\
\hline $\mathrm{FeO}_{\mathrm{l}}$ & $\%$ & $(0.06)$ & 5.48 & 5.05 & 5.07 & 4.76 \\
\hline $\mathrm{Co}$ & $\mu \mathrm{g} / \mathrm{g}$ & $(0.04)$ & 346 & 29.3 & 30.8 & 27.6 \\
\hline $\mathrm{Ni}$ & $\mu \mathrm{g} / \mathrm{g}$ & (18) & 510 & 396 & 405 & 386 \\
\hline $\mathrm{Zn}$ & $\mu \mathrm{g} / \mathrm{g}$ & 2 & 26 & 15 & 17 & 20 \\
\hline Sr & $\mu \mathrm{g} / \mathrm{g}$ & 14 & 179 & 175 & 172 & 176 \\
\hline $\mathrm{Zr}$ & $\mu \mathrm{g} / \mathrm{g}$ & 19 & 183 & 154 & 144 & 153 \\
\hline Cs & $\mu \mathrm{g} / \mathrm{g}$ & 0.02 & 0.14 & 0.12 & 0.11 & 0.12 \\
\hline $\mathrm{Ba}$ & $\mu \mathrm{g} / \mathrm{g}$ & 7 & 138 & 117 & 110 & 118 \\
\hline $\mathrm{La}$ & $\mu \mathrm{g} / \mathrm{g}$ & 0.7 & 12.9 & 112 & 10.6 & 11.3 \\
\hline $\mathrm{No}$ & $\mu \mathrm{g} / \mathrm{g}$ & 1.4 & 19.9 & 17.3 & 16.5 & 17.1 \\
\hline $\mathrm{Sm}$ & $\mu \mathrm{g} / \mathrm{g}$ & 0.21 & 5.94 & 5.19 & 4.90 & 5.25 \\
\hline $\mathrm{Eu}$ & $\mu \mathrm{g} / \mathrm{g}$ & 0.02 & 1.19 & 1.13 & 1.11 & 1.13 \\
\hline $\mathrm{Tb}$ & $\mu \mathrm{g} / \mathrm{g}$ & 0.05 & 1.24 & 1.06 & 1.00 & 1.06 \\
\hline $\mathrm{Yb}$ & $\mu \mathrm{g} / \mathrm{g}$ & 0.15 & 4.23 & 3.69 & 3.49 & 3.68 \\
\hline Lu & $\mu \mathrm{g} / \mathrm{g}$ & 0.020 & 0.586 & 0.513 & 0.485 & 0.518 \\
\hline $\mathrm{Hf}$ & $\mu \mathrm{g} / \mathrm{g}$ & 0.30 & 4.50 & 3.87 & 3.64 & 3.83 \\
\hline $\mathbf{T a}$ & $\mu \mathrm{g} / \mathrm{g}$ & 0.03 & 0.54 & 0.45 & 0.43 & 0.45 \\
\hline Ir & $\mathrm{ng} / \mathrm{g}$ & $(1.0)$ & +16.3 & 12.5 & 11.8 & 125 \\
\hline $\mathrm{Au}$ & $\mathrm{ng} / \mathrm{g}$ & (1.0) & $\$ 9.9$ & 7.4 & 7.4 & 8.9 \\
\hline Th & $\mu \mathrm{g} / \mathrm{g}$ & 0.09 & 2.11 & 1.84 & 1.75 & 1.84 \\
\hline $\mathrm{U}$ & $\mu \mathrm{g} / \mathrm{g}$ & 0.05 & 0.57 & 0.50 & 0.48 & 0.48 \\
\hline $\mathrm{I}_{s} / \mathrm{FeO}$ & & & 84.6 & 44.7 & 39.6 & 52.5 \\
\hline
\end{tabular}

- For lithophile elements, this column contains the sample standard deviation in concentrations for the 88 samples of Unit $A$, thus the values reflects both analytical and sampling uncertainties in this compositionally uniform unit. For siderophile elements (in parentheses), for which concentrations are not normally distributed, this column contains the estimated $1-\sigma$ analytical uncertainty.

$\dagger$ Excludes sample with Ir-rich iron micrometeorite.

‡xcludes samples believed to be contaminated with Au (see text).

immature because they have not been gardened substantially by micrometeorite impact since the formation of North Ray crater approximately $50 \mathrm{Ma}$ ago. Feldspathic fragmental breccias are believed to represent the Descartes formation underlying the Cayley plains at the site (STOFFLER et al., 1985). Like the anorthosite component in $60009 / 10$, the feldspathic fragmental breccias are poor in Sm, but because they are more mafic ( $\sim 80 \%$ plagioclase, by mass, instead of $\sim 99 \%$ ), they have higher abundances of Sc, $6-9 \mu \mathrm{g} / \mathrm{g}$ (Fig. 5).

All soils from the central and southern part of the Apollo 16 site contain some mare material in the form of volcanic glasses, impact glasses, and crystalline basalt (HEIKEN et al., 1973; VANimAN et al., 1976; KOROTEV, 1991; DELANO, 1991. 1992). The abundance of mare material is not known exactly. but is probably about $2-5 \%$ in the $<1 \mathrm{~mm}$ surface fines. The portion of the deep drill core known as Unit B of VANIMAN et al. (1976) (103-187 cm depth, mostly the 60003-60005 sections) is unusual in that it contains an additional $\sim 1 \%$ (absolute) mare material compared to typical surface soil (KOROTEV, 1991). Because Sc concentrations in mare basalts and mare glass are high ( 50 to $90 \mu \mathrm{g} / \mathrm{g}$ ). Sc concentrations in Unit B of 60002-7 are anomalously high (mean: $10.4 \mu \mathrm{g}$ / g; Fig. 8c) and soils from Unit B plot off and to the high-Sc side of the $60009 / 10$ mixing line. Similarly, soil between 26 and $48 \mathrm{~cm}$ deep in the station 4 core also contains an excess of mare material and samples from this unit also plot off the $60009 / 10$ trend (Fig. 8d)

Samples from Units $A$ and $C$ in $60013 / 14$ plot generally along the mixing trend of $60009 / 10$; however, the samples from Unit B with the low $\mathrm{Sm} / \mathrm{Sc}$ ratios and low maturity plot off and to the high-Sc side of the trend (Figs. 5, 8a). No other surface or core soils from the central and southern stations plot in the region of these Unit B soils in Sc-Sm space. Apparently these soils contain a significant abundance of some low-Sm/Sc component. We cannot identify this component with certainty on the basis of the compositional data obtained here, but its general characteristics can be inferred and some possible components can be excluded from consideration.

In terms of Sc and Sm, the low-Sm/Sc samples of Unit B could be explained by starting with a soil such as that of Unit $\mathrm{A}$ and adding anorthosite to lower the concentrations of $\mathrm{Sc}$ and $\mathrm{Sm}$ along the $60009 / 10$ mixing line and also by adding mare material to increase the concentration of Sc ( arrow MB in Fig. 5a). However, addition of mare material to highlands material lowers the $\mathrm{La} / \mathrm{Sm}$ ratio, and La/Sm ratios in 60013/ 14 remains remarkably constant with depth at $2.17 \pm 0.02$ (mean \pm standard deviation) (Fig. 8d). This is essentially the same ratio observed throughout $60009 / 10$ ( La/Sm $=2.16 \pm 0.02:$ KOROTEV, 1991). For comparison, even the $1 \%$ excess abundance of mare material in Unit B of $60001-$ 7 lowers the $\mathrm{La} / \mathrm{Sm}$ ratio of these soils to $2.13 \pm 0.03$ ( KoROTEV, 1991). Thus, because the low-Sm/Sc soils in 60013 / 14 do not also have low $\mathrm{La} / \mathrm{Sm}$ ratios, it is unlikely that the apparent Sc excess is caused by a component with low La/ $\mathrm{Sm}$, such as mare basalt or mare glass.

It is more likely that the low-Sm/Sc component is some type of highlands noritic anorthosite. One potential candidate is regolith such as that from North Ray crater (KOROTEV et al., 1993). Although it is unlikely that ejecta specifically from North Ray crater occurs half a meter deep at station 10 (STOFFLER et al., 1981), it is possible that material similar to that excavated from North Ray crater underlies station 10 and that some crater local to station 10 sampled the same formation. It is clear that if the low-Sm/Sc soils are derived from mixing of a low-Sm/Sc component with typical Unit A soil (Fig. 5a), then the low-Sm/Sc component must be compositionally similar to typical North Ray crater regolith. i.e., it must have an intermediate concentration of Sc (5-9 $\mu \mathrm{g} / \mathrm{g}$ ) and low concentration of Sm (probably $<3 \mu \mathrm{g} / \mathrm{g}$ ). However, low-Sm/Sc soils from $60013 / 14$ are also characterized by low $\mathrm{Na}$ and $\mathrm{Eu}$ concentrations, while most North Ray crater soils have greater $\mathrm{Na}$ and Eu concentrations than do the $60013 / 14$ soils (Fig. $5 \mathrm{~b}$ ). Thus, the low-Sm/Sc component cannot be material such as soil sampled at North Ray crater. Nevertheless, a specific North Ray crater sample might represent the low-Sm/Sc component as some samples satisfy the implied mass balance for all elements determined here, including $\mathrm{Na}$. For example, the mean composition of the low-Sm/Sc soil of Unit B can be modeled as a mixture of $80 \%$ soil from Unit $A$ and $20 \%$ noritic anorthosite with the composition of 67075.11 of WÄNKE et al., 1975 (a friable 

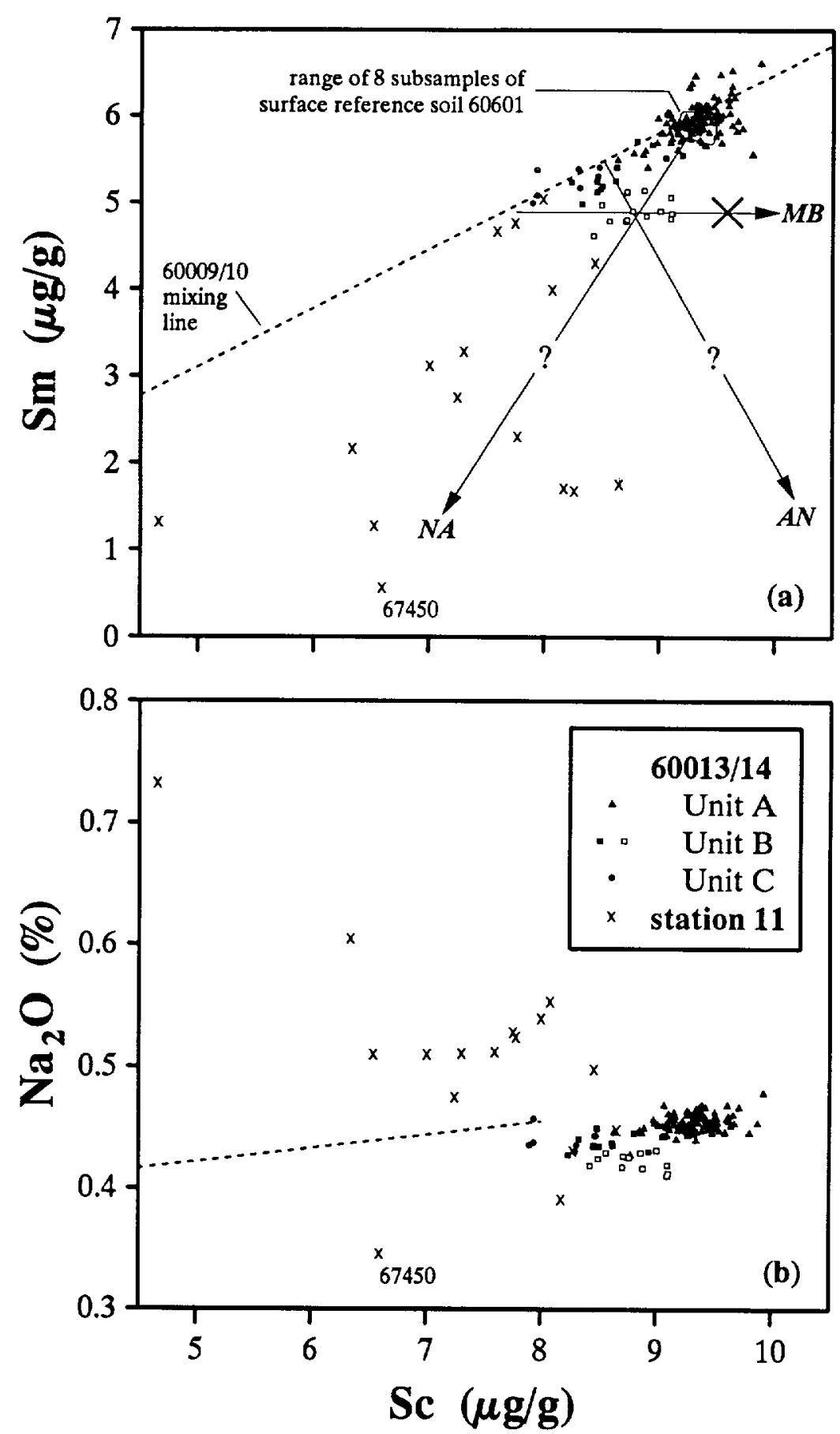

FIG. 5. Comparisons of compositions of $60013 / 14$ samples with soils from North Ray crater at station 11 (Fig. 2). The open squares represent the low-Sm/Sc soils from Unit B of $60013 / 14$, which must contain some low-Sm/Sc component in greater abundance than other soils in the core. a) The dashed line is the $60009 / 10$ mixing line (Fig. $8 \mathrm{~b}$ ). Mixing of soil with the composition of Unit A (Fig. 4) and a low-Sm/Sc, noritic-anorthosite component generally similar in composition to soil from North Ray crater can account for the composition of the low-Sm/Sc soils (arrow NA). b) However, Descartes material such as that excavated from North Ray crater is usually rich in Na (and Eu). Thus, the noritic-anorthosite component is probably from some other source, although some individual North Ray crater samples do satisfy the mixing relationship, such as 67450 (residue fines accompanying 67455). Alternatively, the low-Sm/Sc soils may be a mixture of soil from Units B or C that plots on the $60009 / 10$ mixing line and some low-Sm/Sc component. In this case, the low-Sm/Sc component is more mafic (greater $\mathrm{Sc}$ concentration) than soil from North Ray crater, i.e., an anorthositic norite (arrow AN). The low $\mathrm{Sm} / \mathrm{Sc}$ component is unlikely to be mare basalt (arrow MB, see text). In $b$ ), the dashed line is the mixing line for $60009 / 10$ soils from the feldspathic part of the core only (36-57 cm; see Fig. 6a of KOROTEv, 1991). The X's include all station-11 soils (KOROTEV, 1982 and this work). In a), the station 11 soils that plot near the 60009/10 mixing line (samples 67940, 67960) are dissimilar to the core soils when other elements are considered $(\mathrm{Na}, \mathrm{Mg})$. Data for 60601 are from MCKAY et al. (1986) and KOROTEV ( 1991$)$. 


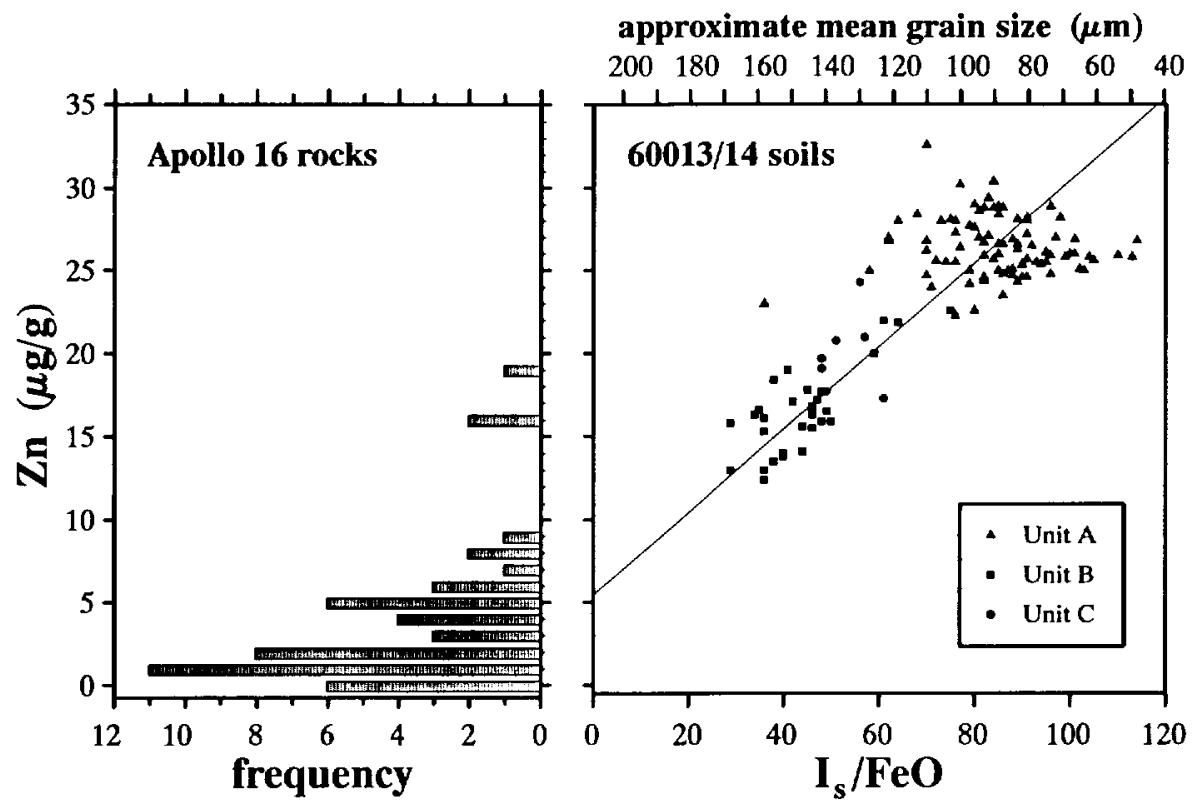

FIG. 6. Concentrations of $\mathrm{Zn}$ increase with increasing $I_{s} / \mathrm{FeO}$. In Apollo 16 soils mean grain size $(d, \mu \mathrm{m})$ also varies inversely with $I_{\mathrm{s}} / \mathrm{FeO}$ approximately by the relationship $I_{s} / \mathrm{FeO}=-0.71 d+148$ (see Fig. 5c of MORRIS, 1976). The diagonal line is a model fit to the data assuming spherical particles of constant diameter $d$ and a uniform layer of 0.12 $\mu \mathrm{g} \mathrm{Zn}$ per square centimeter. The data are generally consistent with a model in which all but about $5 \mu \mathrm{g} / \mathrm{g}$ of the $\mathrm{Zn}$ is surface correlated, which in turn is consistent with $\mathrm{Zn}$ concentrations observed in Apollo 16 rocks $\left(I_{s} / \mathrm{FeO}=0\right)$. Although $I_{s} / \mathrm{FeO}$ decreases with depth in Unit A ( Fig. 3), Zn concentrations in this unit are constant with depth (not shown), suggesting a saturation effect. The histogram shows the distribution of $\mathrm{Zn}$ concentrations in Apollo 16 rocks (mostly polymict breccias, but not necessarily a representative suite, from compilation of Fig. $8.25 \mathrm{f}$ of HASKIN and WARREN, 1991).
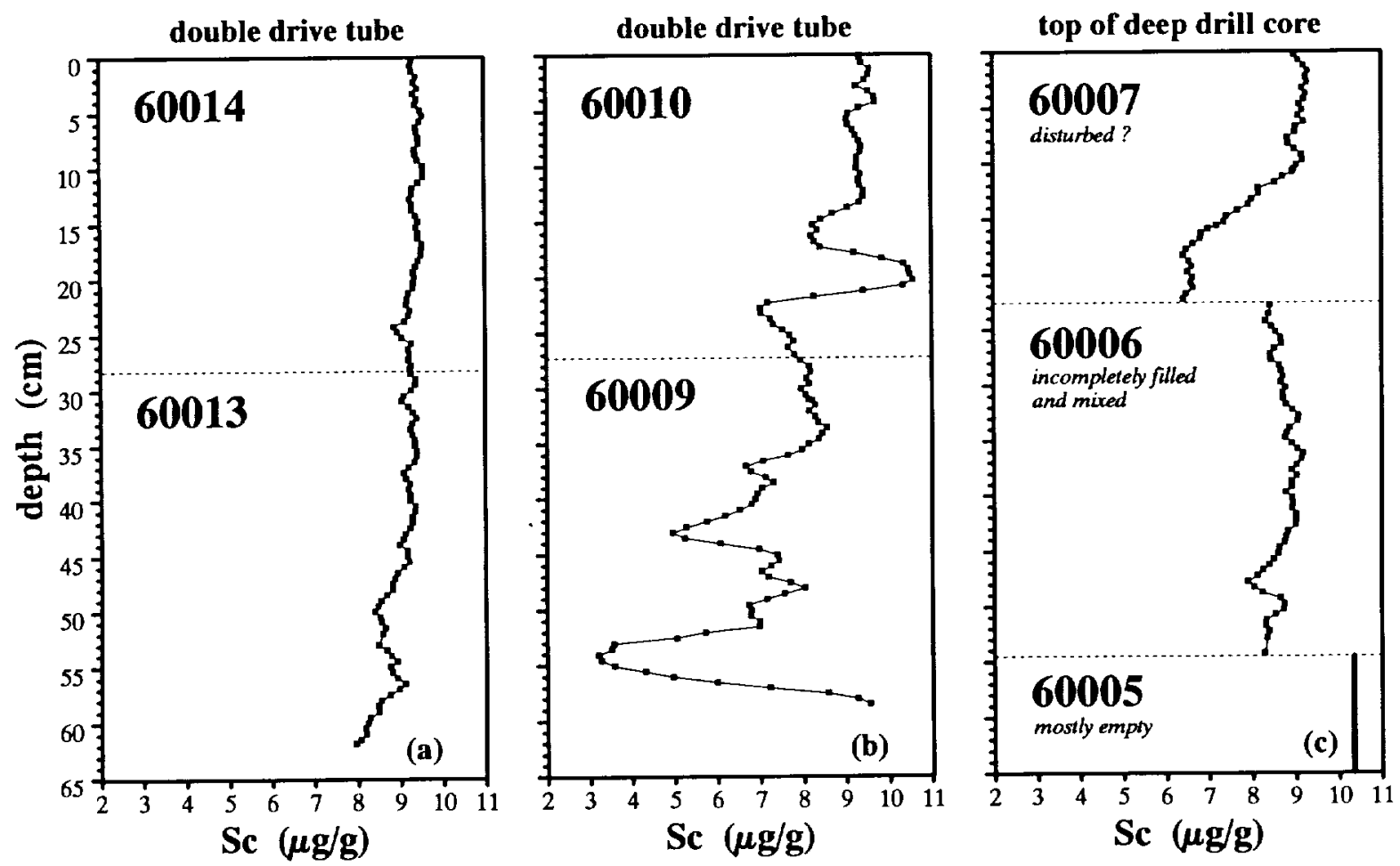

FIG. 7. Scandium profiles for the three station 10 cores. For simplicity, the data have been smoothed ( 3 -point running average, $[1+1+1] / 3)$, with a few anomalous high-Sc points excluded from the mean (nuggets of mare-derived material or mafic melt breccias; see Fig. 4 and KOROTEv, 1991). The top half of the deep drill core is disturbed and stratigraphy is not well preserved; the 60006 and 60005 sections were only partially filled and the contents were mixed (ALLTON and WALTZ, 1980; KOROTEV, 1991). The vertical line in the 60005 section represents the average Sc concentration of the 21 samples from the 60005 section (KOROTEV, 1991). 

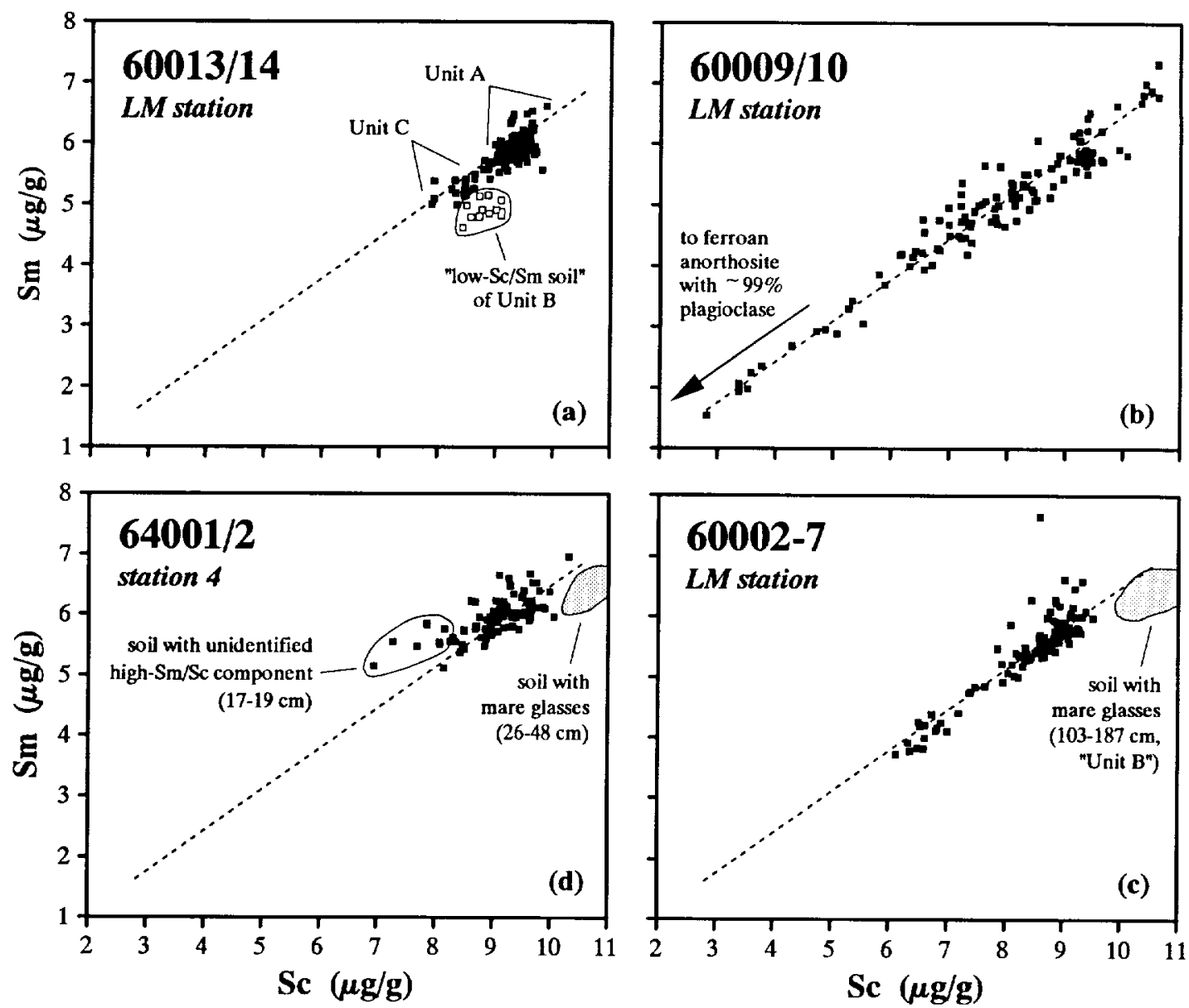

FIG. 8. Comparison of $\mathrm{Sm}$ and $\mathrm{Sc}$ concentrations in samples from the three station-10 cores and station-4 core $64001 / 2$. The diagonal line in each plot is the best-fit line to the $60009 / 10$ data of $(b)$; this line extrapolates to the composition of ferroan anorthosite containing $\sim 99 \%$ plagioclase, very near the origin (KOROTEV, 1991). Thus, samples plotting anywhere on the line have nearly identical $\mathrm{Sm} / \mathrm{Sc}$ ratios. In $64001 / 2$ and $60002-7$ some samples plot to the high-Sc side of the mixing line as a result of a small excess component of mare-derived glass and basalt. For clarity, these samples are not plotted individually, but the field for typical samples is indicated; some samples plot off the figure to higher Sc concentrations. In c), the Na-rich soils from Unit A are excluded for clarity $(187-220 \mathrm{~cm}$ depth; mostly 60001 and 60002). Data from KOROTEV et al. (1984), KOROTEV (1991), and this work (previously unreported data for 64002; see Fig. 10).

ferroan anorthosite; RYDER and NORMAN, 1979) or regolith sample 67450 (Fig. 5). Therefore, if the low-Sm/Sc component is related to material such as that from North Ray crater, it is most likely derived from some specific lithology and is not a mixture of several rock types. The combination of low concentrations of $\mathrm{Na}, \mathrm{Sm}$, and $\mathrm{Eu}$, moderate concentrations of $\mathrm{Sc}(5-20 \mu \mathrm{g} / \mathrm{g})$, and a low $\mathrm{Sm} / \mathrm{Sc}$ ratio is characteristic of moderately mafic members of the ferroan anorthosite suite (WARREN, 1990) of lunar igneous rocks, or brecciated derivatives. In contrast, the higher $\mathrm{Na}$ and $\mathrm{Eu}$ concentrations of the North Ray crater soils are typical of more magnesian lithologies (greater $\mathrm{Mg} / \mathrm{Fe}$; e.g., LINDSTROM and LINDSTROM, 1986).

To account for approximately identical $\mathrm{Sm} / \mathrm{Sc}$ ratios, but lower $\mathrm{Sc}$ and $\mathrm{Sm}$ concentrations, in Unit $\mathrm{C}$ compared to Unit $A$, Unit $C$ must contain a greater abundance of some low-Sc and low-Sm component than does Unit A. This component is probably ferroan anorthosite with a very high modal abundance of plagioclase $(\sim 99 \%)$ because feldspar crystals similar to those found in $60009 / 10$ are abundant in this unit (BASU et al., 1993) and the 60013/14 samples plot on the Sc-Sm trend defined by the $60009 / 10$ samples (Fig. 8 ). A mixture of $87 \%$ average Unit A soil and $13 \%$ plagioclase such as that found in the plagioclase-rich layers of $60009 / 10$ (KoROTEV, 1991) accounts for the average composition of the Unit C soil (Table 1). Because of the relatively small excess of anorthosite in $60013 / 14$ compared to $60009 / 10$, the compositional data alone do not require that the anorthosite component has as much as $99 \%$ plagioclase, as they do in $60009 / 10$ (KOROTEV, 1991 ); however, the anorthosite cannot be substantially more mafic (greater Sc) or the Unit $\mathrm{C}$ soils would have a different $\mathrm{Sm} / \mathrm{Sc}$ ratio and not plot on the $60009 / 10$ trend of Fig. 8.

\section{Stratigraphic Correlation among the Three Station 10 Cores}

The regolith sampled by the three cores is thought to be typical of the Cayley plains in the vicinity of the landing site 
(Fig. 2). The area of the $60013 / 14$ core was smooth in appearance, with no obvious craters and no large rocks; 5-20 $\mathrm{cm}$ blocks were moderately abundant at the surface. The area of $60009 / 10$ was generally flat with centimeter-sized rocks at the surface; the core was taken on the edge of a degraded crater, $50-60 \mathrm{~cm}$ in diameter. The deep drill core was taken in a flat area with abundant 10-15-cm blocks. (Documentation taken from SUTTON, 1980; also MUEHLBERGER et al., 1980.) Because of problems encountered with the rotary drill, the upper half of deep drill core does not preserve a continuous column of regolith and some material has been lost (ALLTON and WALTZ, 1980; KOROTEV, 1991).

For all three cores, maturity generally decreases with depth from the surface, at least over the $0-60 \mathrm{~cm}$ interval sampled by each core (Fig. 9). The same trend is observed in other lunar cores and is attributed to the gardening process on the lunar surface (MORRIS, 1978a) in which lunar soil is mixed at decreasing frequency with increasing depth from the surface by meteorite impact (GAULT et al., 1974; ARNOLD, 1975).

There is thus evidence for a mature surface layer $\sim 40 \mathrm{~cm}$ deep in the LM/ALSEP area of the Apollo 16 site because $I_{s} / \mathrm{FeO}$ profiles for $60001-7$ and $60013 / 14$ overlay down to a depth of $40 \mathrm{~cm}$ ( Fig. 9 ) even though compositional differences are present over the same interval. Stratigraphic variation in maturity can develop independent of any compositional stratigraphy. For example, a meteorite impact can

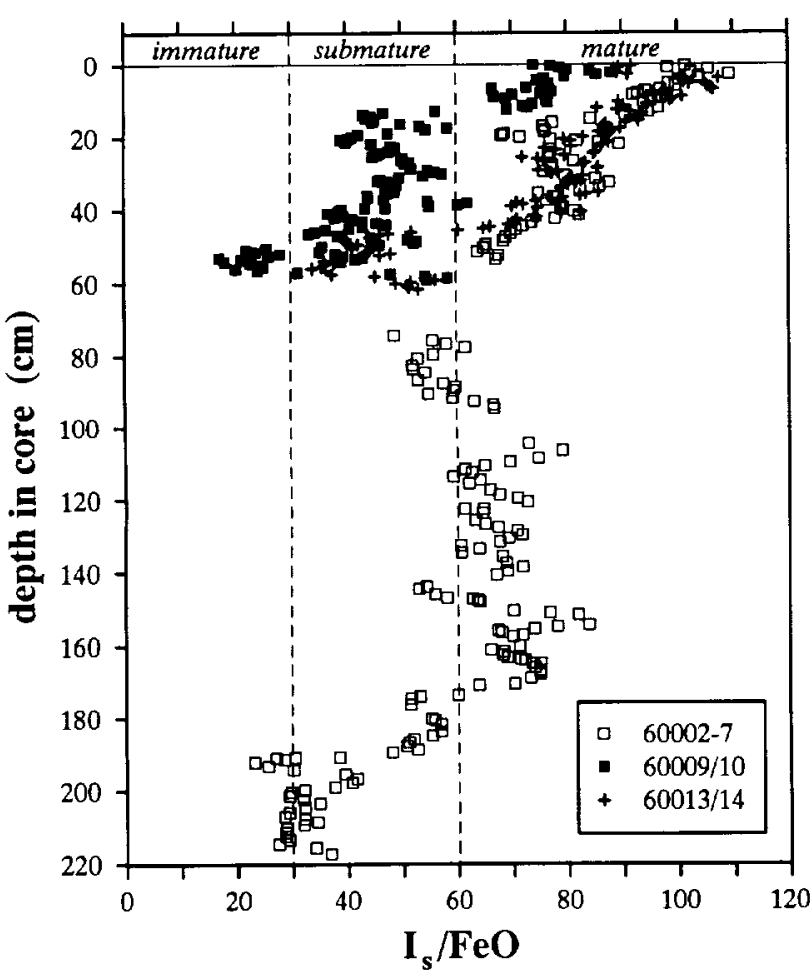

Fig. 9. Comparison of $I_{\mathrm{s}} / \mathrm{FeO}$ profiles for the three station- 10 cores. For this plot, the $I_{s} / \mathrm{FeO}$ data of MORRIS and GOSE (1976) for 60009/10 and of GOSE and MORRIS (1977) for 60002-7 and have been recalculated using concentrations of $\mathrm{FeO}$ reported by KOR. OTEV (1991). (The bit section, 60001 , of the deep drill core was not studied by GOSE and MORRIS, 1977.) This does not make a significant difference for the $60009 / 10$ data. but the values of $I_{s} / \mathrm{FeO}$ for the $60002-7$ core were increased by an average of $\sim 10 \%$. The data have been smoothed, as in Figs. 3a and 7. sample and mix together on a scale of $2 \mathrm{~m}$ (vertical) soils having different compositions but the same maturity. Because smaller impacts are more frequent than larger ones, subsequent maturation (mixing) drives the resultant soil in the direction of compositional homogeneity. It is also possible for a slab of soil initially homogeneous with respect to composition and maturity to become heterogeneous with time because infrequent large impacts bury mature surface soil and deposit immature, compositionally distinct subsurface material at the surface. However, because maturity is acquired only in the upper $\sim 1 \mathrm{~mm}$ of soil during micrometeorite gardening, overall the surface becomes more mature with time.

In part because the surface soil is the most well mixed soil, the soil at the very top of each core is virtually identical in composition among the three cores (Fig. 7). The zones of compositionally similar soil extend from the surface to 44 $\mathrm{cm}$ depth in $60013 / 14$ (i.e., Unit A), to $13 \mathrm{~cm}$ in $60009 /$ 10 , and to $12 \mathrm{~cm}$ in $60001-7$. For example, means and standard deviations for $\mathrm{Sc}$ concentration $(\mu \mathrm{g} / \mathrm{g})$ in the top $10 \mathrm{~cm}$ of each core are $9.44 \pm 0.18$ for $60014,9.35 \pm 0.27$ for 60010 , and $9.11 \pm 0.22$ for 60007 ( $N \approx 20$ samples each; Fig. 4 ). (The lower value for the deep drill core may be because the soil at the top of the core was mixed with the more feldspathic soil underneath during the drilling process; KOROTEV, 1991). Nearly all surface and trench soils from the central stations ( 1,2 , and 10) are similar in composition (KOROTEV, 1981). Even the top $10 \mathrm{~cm}$ of the station 4 core, $3.7 \mathrm{~km}$ to the south (Fig. 2), is similar ( $\mathrm{Sc}=9.11 \pm 0.36$; Fig. 10). Although we use $\mathrm{Sc}$ here as an example, the similarities extend to all elements measured. The only surface and trench soils that are dissimilar in composition are submature and immature soils collected near craters (e.g., samples 60051, 61221); these contain higher abundances of anorthosite and feldspar grains (HEIKEN et al., 1973; MORRIS et al., 1983) and, consequently, have lower concentrations of Sc, Sm, and other elements characteristic of mafic rocks.

At depth, however, each of the three station 10 cores contains units or layers of soil compositionally dissimilar to any found in the other station 10 cores or at the surface. The two bands of low-Sm/Sc soil discussed above in Unit B of 60013 / 14 have no counterpart in $60009 / 10$ and $60001-7$. The component causing the low $\mathrm{Sm} / \mathrm{Sc}$ ratios may occur in the other two cores, but not in sufficient abundance to alter the $\mathrm{Sm} / \mathrm{Sc}$ ratio of any region of soil to the extent seen in $60013 /$ 14. Likewise, in $60009 / 10$, the layer of soil at $18-21 \mathrm{~cm}$ depth (Unit 2 of DUKE and NAGLE, 1976) is dissimilar to any soil in the other two cores (Figs. $7,8 \mathrm{~b}$ ). This submature soil contains a greater abundance of melt breccia than the soil at the tops of the cores (MCKAY et al., 1977). In 600017 , the soil of Unit B (103-187 cm depth) is unusual in containing an excess of mare material, as discussed above. At the bottom of this unit $(177-187 \mathrm{~cm})$ the soil is also enriched in siderophile elements because of an unusually high abundance of chondritic material, a feature not seen in the other cores. Between $187 \mathrm{~cm}$ and the bottom of the deep drill core at $220 \mathrm{~cm}$ (Unit A of VANIMAN et al., 1976; primarily the 60001 and 60002 sections of the core) is an immature to submature soil (Fig. 9) that is unusually rich in $\mathrm{Na}$, possibly because of a component of regolith breccia of unknown derivation. Nearly all of these compositionally distinct layers are 


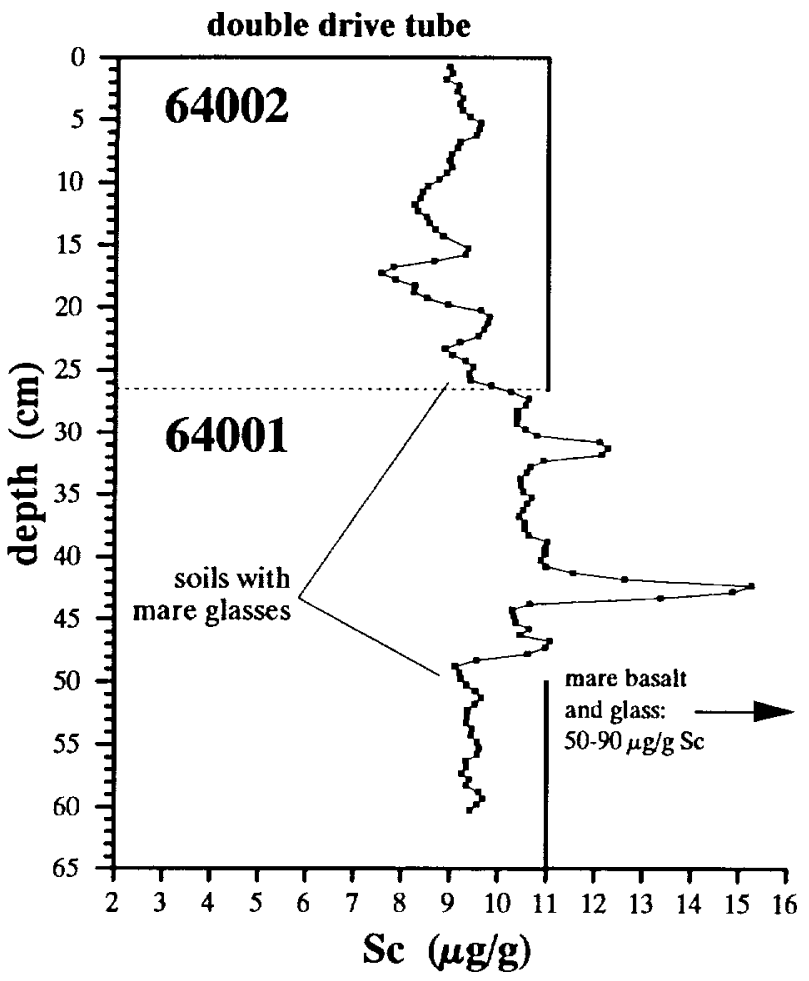

FIG. 10. Scandium profile for the station 4 core from Stone mountain, about $4 \mathrm{~km}$ south of station 10 (Fig. 2). For comparison with Fig. 7, the figure is drawn to the same scale, although Sc concentrations are anomalously high in some regions of the core as a result of an excess of mare material (KOROTFV and MORRIS, 1984: BASU and MCKAY, 1984; DELANO, 1991). The top $\sim 10 \mathrm{~cm}$ of soil in the core, as well as the bottom $12 \mathrm{~cm}$, is nearly identical in composition to the soil from the surface of station 10 . This is a major argument that station 4 is not representative of the Descartes formation, as expected from premission planning (MUEHLBERGER et al., 1980), but that the surface regolith (at least) is typical of the Cayley plains. The feature at $17-19 \mathrm{~cm}$ depth is unusual in containing some unidentified component with a high Sm/Sc ratio (Fig. 8d), in contrast Unit B of $60013 / 14$.

less mature than the surface soil. (Summary above based on KOROTEV, 1991.)

Together, these observations indicate that the compositional variation with depth that occurs in the regolith of the Cayley plains results from incomplete mixing, on the scale of the core depths, of the wide assortment of lithologies of which the plains are composed and that the surface regolith $(0$ to $10+\mathrm{cm}$ depth $)$ is simply the well-mixed average. The origin of the Cayley plains is controversial, but the plains are almost certainly a deposit of ejecta related primarily or secondarily to the Imbrium impact, and possibly Orientale (HODGES and MUEHLBERGER, 1981; SPUDIS, 1984; STOFFLER et al., 1985; WILHELMS, 1987). The thickness of the plains at station 10 is estimated to be $70-220$ (COOPER et al., 1974). However, the regolith thickness is thought to be only $10-15 \mathrm{~m}$, and $1-10 \mathrm{~m}$ blocks are observed in the walls of South Ray crater within $\sim 60 \mathrm{~m}$ of the preimpact surface (KovaCH and WatkinS, 1973; Muehlberger et al., 1980). Judging by rock fragments collected at the surface, the Cayley plains consist of impact melt breccias of a wide variety of compositions, dimict breccias, regolith breccias, granulitic and fragmental breccias, anorthosites of variable composition and affinity, and a few mafic, plutonic rocks (e.g., JAMES, 1981). Undoubtedly after deposition, these rocks occurred as a rubble layer with some large blocks, some fine debris, and a continuum of sizes in between. The size distribution was larger than that now observed at the surface and many rocks were large compared to the dimensions of the cores. Some rocks were exposed at the surface, and the plains were not as smooth as they were when visited by the astronauts. Since formation of the plains more than $3 \mathrm{Ga}$ ago, the surface has been subjected to continual bombardment by meteoroids that have produced a few craters on the order of a kilometer in diameter (e.g.. North Ray crater) but many smaller ones. This bombardment has been sufficient to produce a layer of fine debris at the surface of the site. The fact that mature surface soils from the central stations $(1,2,10)$ are all very similar to each other in composition and generally similar to surface soils from the southern stations $(4,5,6,8,9)$ indicates that on the lateral scale of up to a few kilometers, any column through the Cayley regolith (10-100 $\mathrm{m}$ deep) is going to encounter the same suite of lithologies in roughly the same proportions as any other such column. However locally, even decimeters below the surface, nonuniformity exists on the scale of centimeters that is ultimately associated with earlier nonuniformities on the scale of meters to tens of meters. An impact large enough to excavate material from more than even a few meters depth may sample one or more compositionally distinctive lithologies with little previous surface exposure, or lenses of old regolith. A similarly-sized impact $50 \mathrm{~m}$ away may sample a different set of lithologies or the same set of lithologies occurring in different proportions.

Thus, it is unlikely that any of the subsurface, compositionally distinct units of soil observed in these cores represents a stratigraphically contiguous layer extending over the distances of 40 to 50 meters that separate the cores. The low $\mathrm{Sm} / \mathrm{Sc}$ ratio and low maturity of Unit B of $60013 / 14$ may be the result of one or more impacts into a single subsurface boulder. Other than the soil at the surface, the only likely correlation among the cores involves plagioclase. Each of the cores contains regions that correspond compositionally to soil such as that at the surface. but diluted to varying degrees with nearly monomineralic plagioclase such as that occurring in ferroan anorthosite. This is most pronounced in 60009/ 10 where the soil between 52 and $55 \mathrm{~cm}$ depth corresponds to a 66:34 mixture of plagioclase and surface-soil-like component; other areas or the core contain less extreme plagioclase enrichment (Fig. 8). The most plagioclase-rich region of 60001-7 occurs between 17.5 and $22.5 \mathrm{~cm}$ depth (the 60007 section) where the mixing ratio is $32: 68$. (The plagioclase-rich layer may extend below $22.5 \mathrm{~cm}$ as the 60006 and 60005 core sections were incompletely filled, but it is unlikely to be more than about $10 \mathrm{~cm}$ wider; KOROTEV, 1991.) In $60013 / 14$, between $58 \mathrm{~cm}$ and the bottom of the core at 62 $\mathrm{cm}$, the mixture averages 13:87 (plagioclase:surface-soil-like component); more feldspathic soil may occur below this as the trend appears to be more feldspathic with depth (Fig. 4a). In each case the plagioclase-rich soil is immature and coarser grained than is the soil at the surface. 
Note that a soil of intermediate maturity (e.g., Unit $\mathrm{C}$ of $60013 / 14$ ), although compositionally equivalent to a mixture of surface soil and plagioclase, cannot literally be such a mixture because simple admixture of plagioclase to a mature soil will not lower $I_{s} / \mathrm{FeO}$. This is because dilution with plagioclase affects $I_{s}$ (FMR intensity) and the FeO concentration to the same relative extent as both quantities measure effectively zero in plagioclase. Thus, the lower maturity of more feldspathic soils indicates that the Fe-bearing components have received less surface exposure than has typical surface soil. Unit $C$ appears to consist of the same components as Unit A, but with a greater proportion of plagioclase and lower overall surface exposure.

Particularly conspicuous in its absence as a cause of compositional variation with depth in these cores is mafic, ITErich impact melt breccia. Mass balance models indicate that such breccias must be major components of the soil $(\sim 35 \%$ at station 10) and are the principal carriers of incompatible trace elements (KEMPA et al., 1980; MORRIS et al., 1986). Yet, except for the narrow band at $18-21 \mathrm{~cm}$ depth in $60009 /$ 10 (Fig. 7), systematic compositional variation with depth is not caused by units of soil containing an excess of mafic melt breccia. The fact that most samples from the cores lie along linear trends between mature soil and plagioclase on plots involving elements like Sc and Sm (e.g., Fig. 8) indicates that the mafic and ITE-bearing components of the soils such as the mafic melt breccias are well mixed compared to the plagioclase component. This implies that subsurface blocks of anorthosite volumetrically predominate over blocks of mafic melt breccia.

\section{Metallic Iron, Siderophile Elements, and Anomalous Iron Micrometeorite}

Concentrations of metallic iron $\left(\mathrm{Fe}^{0}\right)$ determined magnetically are highly correlated with those of $\mathrm{Ni}$ determined by INAA because Fe- $\mathrm{Ni}$ metal containing about $6-7 \% \mathrm{Ni}$ is the major carrier of both constituents in samples with high metal concentrations (Fig. 11). Samples at depths of 4, 28, and $34 \mathrm{~cm}$ contain nuggets or aggregates of metal grains (possibly enclosed in silicates), leading to anomalously high concentrations of $\mathrm{Fe}^{0}, \mathrm{Ni}$, and $\mathrm{FeO}$ (total $\mathrm{Fe}$ as $\mathrm{FeO}$ ) and low values for $I_{s} / \mathrm{FeO}$ (Figs. 3b-d, 11 ). Similar behavior is observed in other lunar regolith samples, particularly those from Apollo 16 (GOSE and MORRIS, 1977; MORRIS et al., 1979; KOROTEV, 1982, 1991; Korotev et al., 1984). With

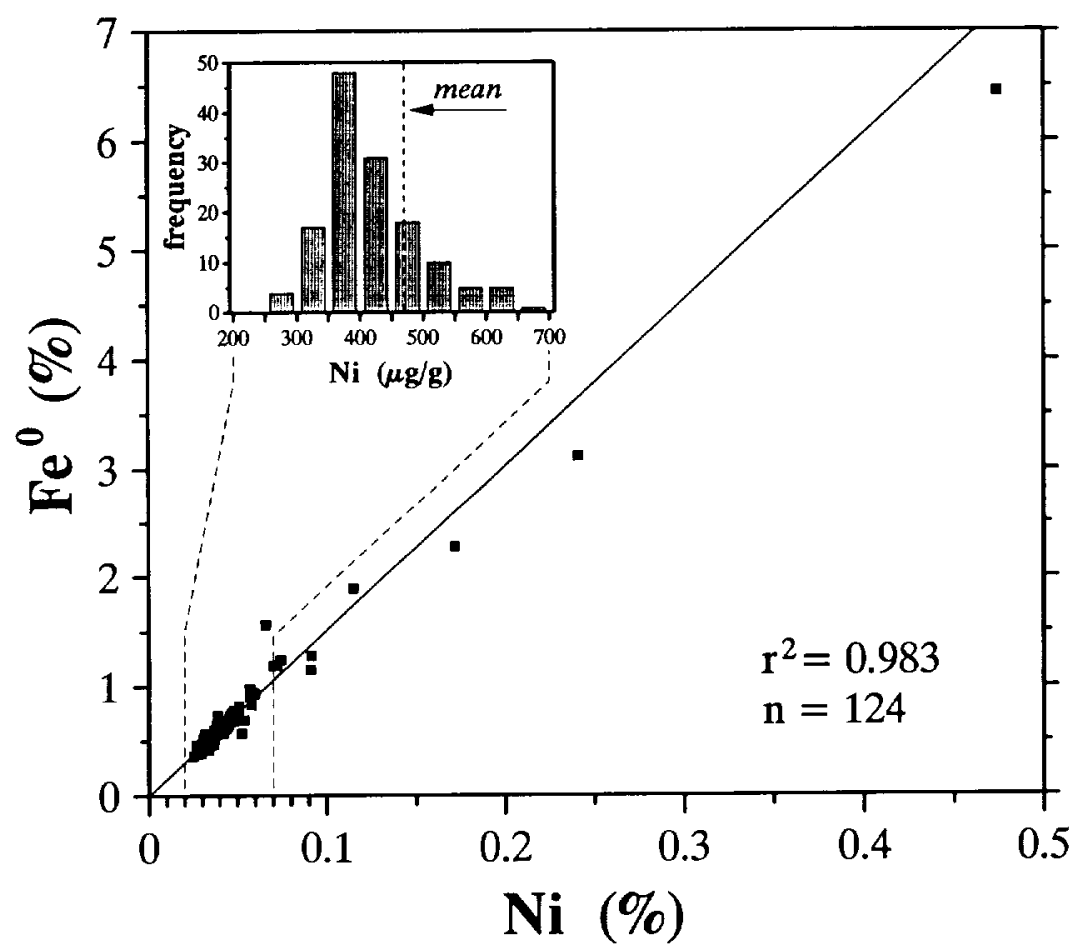

FIG. 11. Concentrations of metallic iron ( $\mathrm{Fe}^{0}$, determined magnetically) are highly correlated with those of $\mathrm{Ni}$ (determined by INAA) because of nonuniform distribution of meteoritic metal among the samples. The diagonal line represents a weighted linear regression in which $\mathrm{Ni}$ and $\mathrm{Fe}^{0}$ concentrations are weighted by $10 \%$ of their values. (This procedure presupposes that scatter about the line is caused mostly by variation in $\mathrm{Fe} / \mathrm{Ni}$ ratio of the metal grains and not analytical uncertainty. As the standard deviations in relative residuals for both $\mathrm{Fe}^{0}$ and $\mathrm{Ni}$ are approximately $9 \%$, which exceeds the analytical uncertainties, the assumption is probably valid.) The line has an intercept effectively at the origin with a slope of $15.1 \pm 0.1$ (95\% confidence), which leads to an average $\mathrm{Ni}$ concentration in the meteoritic metal of $6.6 \%$ (essentially, 1/15.1). (As discussed in Samples and Methods, the magnetic measurements give total concentrations of $\mathrm{Fe}^{0}$ and $/$ or $\mathrm{Fe}-\mathrm{Ni}$ alloys for alloys having $<15 \mathrm{wt}$. \% $\mathrm{Ni}$.] The same $\mathrm{Fe}^{0} / \mathrm{Ni}$ slope (15.0) was obtained on samples from the 64001 core by KOROTEV et al. (1984); however, note that in that paper the estimate of the average $\mathrm{Ni}$ concentration in the metal was calculated incorrectly. 
$6.4 \% \mathrm{Fe}^{0}$ and $4740 \mu \mathrm{g} / \mathrm{g} \mathrm{Ni}$, the sample at $34 \mathrm{~cm}$ depth has the greatest concentration of $\mathrm{Fe}-\mathrm{Ni}$ metal we have observed in more than 1000 lunar soil samples (caused by a $3.3-\mathrm{mg}$ nugget. Table 2). The two other samples analyzed from this depth interval have normal concentrations of siderophile elements (Samples and Methods). Approximately $10 \%$ of the iron in typical, mature Apollo 16 soil is Fe-Ni metal, but that proportion is highly variable among the small samples analyzed here. This is why we choose Sc instead of Fe to represent the abundance of mafic minerals in the figures.

Compositions and masses of the metal grains in these metal-rich samples can be estimated from the difference in siderophile-element concentrations between the metal-rich samples and the average of stratigraphically proximate samples, assuming that the sum of the concentrations of $\mathrm{Fe}, \mathrm{Ni}$, and $\mathrm{Co}$ is $100 \%$ in the metal. Of the four samples with more than $1000 \mu \mathrm{g} / \mathrm{g} \mathrm{Ni}$, the estimated compositions of metal grains in two of them ( 28 and $34 \mathrm{~cm}$ depth) are compositionally consistent with metal such as that found in mafic impact melt breccias at Apollo 16 , i.e., $6-7 \% \mathrm{Ni}, \mathrm{Ni} / \mathrm{Co}$ $\approx 16$, subequal concentrations of $\mathrm{Ir}$ and $\mathrm{Au}$ at the $1 \mu \mathrm{g} / \mathrm{g}$ level, and subchondritic $\mathrm{Ir} / \mathrm{Ni}$ and $\mathrm{Ir} / \mathrm{Au}$ ratios (Table 2, Fig. 12, and KOROTEV, 1987b, 1990). A third grain $(58 \mathrm{~cm}$ depth) is probably also from (or contained in) a mafic melt breccia, but the Ir concentration is anomalously low (e.g., JOLLifF et al., 1991). With nearly chondritic $\mathrm{Ni} / \mathrm{Co}$ and $\mathrm{Ir} /$ Au ratios and $8.7 \% \mathrm{Ni}$, the fourth grain $(4.0-4.5 \mathrm{~cm}$ depth) appears to be metal from an H chondrite (RAMBALDI, 1977).

The sample of soil at $2.0-2.5 \mathrm{~cm}$ depth (split 60014,133 of 60014,19 ) is highly unusual in having $427 \mathrm{ng} / \mathrm{g} \mathrm{Ir}$, but normal concentrations of $\mathrm{Fe}, \mathrm{Ni}, \mathrm{Co}$, and $\mathrm{Au}$. This leads to an exceedingly high chondrite-normalized $\mathrm{Ir} / \mathrm{Ni}$ ratio of 17 (Fig. 12). The cause of this anomaly is an agglutinate particle $149 \mu \mathrm{g}$ in mass consisting largely of an anomalous iron micrometeorite (Table 2). This particle, which contains 148 $\mu \mathrm{g} / \mathrm{g}$ Ir, is discussed more fully elsewhere (Jol.t.IFF et al., 1993).

\section{IMPLICATIONS AND CONCLUSIONS}

The Apollo 16 landing site was chosen, in part, because it was atypical in having two relatively young, bright ray craters, North and South Ray, in close proximity (MUEHLBERGER et al., 1980). South Ray crater was not visited on the mission, but North Ray crater was, and soil near the crater differs in composition from surface soils distant from the crater in being more aluminous and having lower concentrations of incompatible trace elements. Except near North Ray crater, most soil samples taken at the surface (upper $10 \mathrm{~cm}$ ) of the Apollo 16 site are mature and remarkably uniform in composition from place to place (KOROTEV, 1981). If viewed by remote techniques with resolutions on the order of tens to hundreds of meters, the uniformity of the Apollo 16 surface might lead to the incorrect conclusion that the site is dominated by a single lithology when, in fact, the Apollo 16 regolith is a mixture of a number of volumetrically significant lithologies that vary widely in composition (e.g., JAMES, 1981; KOROTEV, 1991 ).

Data presented here suggest that if the top half-meter of regolith could be removed from the site, there would be a significant increase in variation of the composition and maturity of grab samples taken on the scale of $\sim 50$ meters lateral distance at the new surface. However, these variations may not be perceived in geochemical data obtained from lunar orbit and would be largely irrelevant from the regional perspective.

The core data also indicate that half a meter below the surface, regolith in the immediate vicinity of the landing area is somewhat more anorthositic and much less mature then at the surface. The anorthosite component at depth is plutonic ferroan anorthosite containing $\sim 99 \%$ plagioclase. It is compositionally dissimilar to the more mafic ( $\sim 80 \%$ plagioclase $)$ feldspathic fragmental breccias characteristic of the ejecta from North Ray crater, $5 \mathrm{~km}$ to the north. It is possible that the ferroan anorthosite component of the cores was emplaced at station 10 by a single impact event. For example, ferroan anorthosite is thought to be a major component of ejecta from recently formed South Ray crater, $6 \mathrm{~km}$ to the southwest (JAMES, 1981), and ejecta from South Ray crater occurs discontinuously at the surface of station 10 now (SCHABER, 1981). However, it is unlikely that South Ray crater is the source of the anorthosite in the station 10 cores because the anorthosite is buried too deeply (STOFFLER et al., 1981) and the overlying surface soil is too mature to have developed by in situ maturation since formation of South Ray crater $2 \mathrm{Ma}$ ago (MORRIS, 1978a). Nevertheless, the presence of ferroan anorthosite in both the South Ray crater ejecta and at depth in the station 10 cores indicates that ferroan anorthosite is a

Table 2. Estimated composition of mctal in samples with anomalously high siderophile element concentrations.

\begin{tabular}{lcccccccccl}
\hline sample & depth & mass & Fe & Co & Ni & Ir & Au & \multicolumn{2}{c}{ CI-normalized } & likely source \\
& $\mathrm{cm}$ & $\mathrm{mg}$ & $\%$ & $\%$ & $\%$ & $\mu \mathrm{g} / \mathrm{g}$ & $\mu \mathrm{g} / \mathrm{g}$ & $\mathrm{Ni} / \mathrm{Co}$ & $\mathrm{Ir} / \mathrm{Au}$ & \\
\hline $60014,133^{*}$ & $2.0-2.5$ & 0.10 & 92.9 & 0.46 & 6.6 & $225^{*}$ & $<3$ & 0.65 & $>22$ & iron micrometeorite \\
60014,136 & $4.0-4.5$ & 1.1 & 90.8 & 0.45 & 8.7 & 4.6 & 1.1 & 0.88 & 1.3 & H-chondrite \\
60014,183 & $27.5-28.0$ & 0.9 & 92.9 & 0.43 & 6.7 & 0.7 & 1.5 & 0.72 & 0.13 & ancient melt breccia \\
60013,164 & $34.2-34.7$ & 3.3 & 92.6 & 0.43 & 7.0 & 1.6 & 1.6 & 0.75 & 0.29 & ancient melt breccia \\
60013,211 & $57.7-58.2$ & 0.9 & 94.0 & 0.45 & 5.6 & $<0.3$ & 1.4 & 0.57 & $<0.06$ & ancient melt breccia? \\
\hline
\end{tabular}

* For the other samples listed here, the metal compositions were estimated from bulk soil analyses, as described in the text. For the iron micrometeorite in 60014,133 , the composition was estimated from direct analysis of a separated agglutinate particle (JollifF et al., 1993). The particle ( $149 \mu \mathrm{g}$ in mass) contained $62.2 \%$ total iron, of which we estimate $1.2 \%$ to be $\mathrm{Fe}^{2+}$ and $61.0 \%$ to be $\mathrm{Fe}^{0}$ based on the $\mathrm{Sc}$ concentration of the particle $(3.1 \mu \mathrm{g} / \mathrm{g})$ and the typical $\mathrm{Fe}^{2+} / \mathrm{Sc}$ ratio of Apollo 16 regolith (from Table 1). The listed composition assumes that the estimated $\mathrm{Fe}^{0}$ and all the $\mathrm{Ni}, \mathrm{Co}$, Ir, and $\mathrm{Au}$ in the particle is contained the metal, that the sum of these constituents in the metal is $100 \%$, and that all of the Sc is in the silicates. These assumptions also lead to the results that the particle is $66 \%$ metal and $34 \%$ lunar silicate (by mass) and that the silicates have $9.2 \mu \mathrm{g} / \mathrm{g} \mathrm{Sc}$, a reasonable value for soils from Unit A (Table 1). 

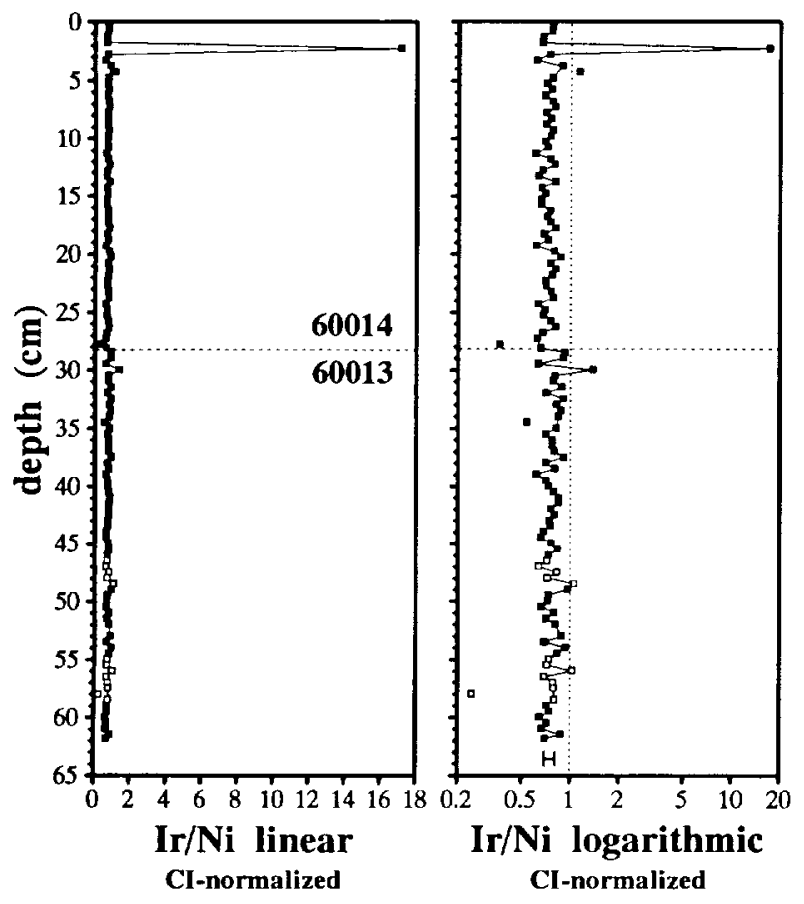

Fic;. 12. Profiles of chondrite-normalized Ir/Ni ratios in 60013/ 14. The four samples not connected by the solid line that connects the majority of points are metal rich, i.e., they are the high- $\mathrm{Ni}$, high $\mathrm{Fe}^{0}$ samples of Fig. 3. The metal in these four samples probably occurs as single grains or possibly aggregates in the milligram mass range (Table 2). In the three samples with low-Ir/Ni ratios, the metal most likely derives from ancient Apollo 16 impact melt breccias, which contain an abundance of metal with subchondritic $\mathrm{Ir} / \mathrm{Ni}$ and Ir/Au ratios (KOROTEv, 1987b, 1990). The fourth sample (4.0-4.5 $\mathrm{cm}$ depth) has a ncarly chondritic Ir/Ni ratio, suggesting the metal probably derives from an ordinary chondrite (Table 2). Most samples have Ir/ $\mathrm{Ni}$ ratios between these two extremes as $\mathrm{Ir}$ and $\mathrm{Ni}$ in typical samples derives subequally from the ancient melt breccias, of which the soil is in large part composed, and chondritic micrometeorites that are continually striking the lunar surface (KOROTFv, 1987a). The sample at $2.0-2.5 \mathrm{~cm}$ depth is highly enriched in $1 \mathrm{r}$ because it contains a small particle $(0.15 \mathrm{mg})$ consisting largely of an iron micrometeorite with an extremely high Ir concentration (JoLl.IFF et al., 1993).

major, regional subsurface lithology. Thus, one or several smaller impacts local to station 10 may have contributed the ferroan anorthosite found in the cores.

The peculiar aspect of the anorthosite component of $60009 / 10$ (with certainty) and the other two cores (with less certainty hecause of the lower abundances) is its nearly monomineralic nature. With $\sim 99 \%$ plagioclase, it is less mafic than typical large samples $(>10 \mathrm{~g})$ of ferroan anorthosite collected at the surface (KOROTEV, 1991; WARREN, 1990), which is primarily ejecta from South Ray crater. This provides weak evidence that the anorthosite in all three cores derives from a common source, perhaps by a common impact.

We do not know for certain whether Apollo 16 ferroan anorthosite is a lithology of the Cayley plains, i.e., occurring as scattered subsurface blocks deposited in the plains-forming event and excavated by South Ray and other cratering events, or whether it is a sub-Cayley lithology occasionally excavated by larger impacts that puncture the Cayley deposit and expose underlying material (Descartes formation?). If the feldspathic fragmental breccias ejected from North Ray crater are typical of the material underlying the Cayley plains in the vicinity of the site, then the ferroan anorthosite must be primarily a Cayley component because compositional variation in the regolith of the central and southern stations does not involve a North-Ray-crater-like component.

From the point of view of regolith dynamics it would probably have been more interesting if the three cores had been taken closer together, perhaps a few meters apart. From the perspective of site geology, however, the 40-50 $\mathrm{m}$ spacing tells us that ferroan anorthosite with a very high modal abundance of plagioclase plays some unique role in the subsurface geology of the landing area.

Acknowledgments-This work was funded by NASA grant NAG 9 56 to L. A. Haskin (RLK) and R TOP 152-17-40-21 to D. S. McKay (RVM). We thank Dr. H. V. Lauer, Jr. (Lockheed ESC. Houston, TX) for the ferromagnetic resonance measurements, B. L. Jolliff and K. M. Rockow for assistance in neutron activation analysis, and L. A. Haskin for the compilation of $\mathrm{Zn}$ data in Apollo 16 rocks. Reviews by $\mathrm{A}$. Basu and $\mathrm{G}$. Heiken improved the manuscript.

Edirorial handling: S. R. Taylor

\section{REFERENCES}

AIITON J. H. and WAL.TZ S. R. (1980) Depth scales for Apollo 15. 16, and 17 drill cores. Prese. Apollo 11 Lamar Sci. Comf. 14631477.

ARNOL.D J. R. ( 1975 ) Monte Carlo simulations of turnover processes in the lunar regolith. Proc oth Lunar Sci. Confi. 2375-2395.

BASU A. and MCKAY D. S. (1984) Petrologic profile of Apollo 16 regolith at station 4. Proc. 15th L.tunar Planet. Sci. Conf.. C133C. 142.

BASU A., MC BRIDF K., WFNTWORTH S. J., and MC Kay D. S. (1993) Apollo 16 core $60013 / 14$ as a product of path I and path II regolith evolution processes. Lunar Planet. S‘i. XXN. 75-76 (abstr.).

BOZARTH R. M. (1951) Ferromagnetism. van Nostrand.

COOPER M. R. Kovach R. L.. and Watkins J. S. (1974) Lunar near-surface structure. Rev. Geophys. Space Phys. 12, 291-308.

DELANO J. W. (1991) Major element compositions of glasses in Apollo 16 core 64001 : Constraints on the mare component. Lunar Planet Sci XXII, 303-304 (abstr.).

DEL_ANO J. W. (1992) Major-element composition and glasses in Apollo 16 cores 60014 (station 10) and 64001 (station 4). Lunar Planct. Si. XXIII. 303-304 (abstr.).

DUKF: M. B. and NAGLE J. S. (1976) Lunar Corc Catalog (and Supplements). JSC 09252. NASA Johnson Space Center.

GaUi. D. E., HORZ F., BROWNLEE D. E., and HARTUNG J. B. (1974) Mixing of the lunar regolith. Proc. 5th Lunar Sci. Conf. 23652386.

GoSI: W. A. and MORRIS R. V. (1977) Depositional history of the Apollo 16 deep drill core. Proc. 8th Lumar Sci. Comli. 2909-2928.

HASKIN L. A. and WARREN P. H. (1991) Lunar chemistry. In Lunar Sortrcehook (ed. G. Heiken et al.), Chap. 8, pp. 357-474. Cambridge Univ. Press.

HEIKEN G. H.. MCKAY D. S., and FRUI.AND R. M. ( 1973) Apollo 16 soils: Grain size analyses and petrography. Proc. 4 th $\mathrm{Lm}$ inar $S_{\mathrm{C}} \mathrm{i}$ Conf. 25I-265.

Hodges C. A. and Muehl.berger W. R. (1981) K. Summary and critique of geologic hypotheses. In Geology of the Apollo It a rea. Cenral Lunar Mighlands (ed. G. E. ULRICH et al.); USGS. Prof. Paper 1048, pp. 215-230.

JAMES O. B. (1981) Petrologic and age relations of the Apollo 16 rocks: Implications for subsurface geology and the age of the Nectaris basin. Proc. I2th Lunar Planer. Sci. Conf., Part B, 209-233. 
JollifF B. L., KOROTEV R. L., and HASKIN L. A. ( 1993) An iridiumrich iron micrometeorite with silicate inclusions from the Moon. Lunar Planet. Sci. XXIV, 729-730 (abstr.).

JOLLIFF B. L., KoROTEV R. L., and HASKIN L. A. (1991) A ferroan region of the lunar highlands as recorded in meteorites MAC88104 and MAC88105. Geochim. Cosmochim. Acta 55, 3051-3071.

KeMPa M. J., PAPIKe J. J., and White C. (1980) The Apollo 16 regolith: A petrographically-constrained chemical mixing model. Proc. I Ith Lunar Planet. Sci. Conf., 1341-1355.

KOROTEV R. L. (1981) Compositional trends in Apollo 16 soils. Proc. 12th Lunar Planet. Sci. Conf., Part B, 577-605.

Korotev R. L. ( 1982 ) Comparative geochemistry of Apollo 16 surface soils and samples from cores 64002 and 60002 through 60007 . Proc. 13th Lunar Planet. Sci. Conf., A269-A278.

KOROTEV R. L. (1987a) The nature of the meteoritic components of Apollo 16 soil, as inferred from correlations of iron, cobalt. iridium. and gold with nickel. Proc. 17th Lunar Planet. Sci. Conf., E447-E46I.

KOROTEV R. L. (1987b) The meteoritic component of Apollo 16 noritic impact melt breccias. Proc. 17th Lunar Planet. Sci. Conf., E491-E512.

KOROTEV R. L. (1990) Cobalt and nickel concentrations in the komatiite component of Apollo 16 polymict samples. Earth Planet. Sci. Lett. 96, 481-489.

KOROTEV R. L. (1991) Geochemical stratigraphy of two regolith cores from the Central Highlands of the Moon. Proc. Lunar Planet. Sci. 21, 229-289.

KoroteV R. L., MORRIS R. V., and LAUER H. V. JR. ( 1984) Stratigraphy and geochemistry of the Stone Mountain core (64001) 2). Proc. 15th Lunar Planet. Sci. Conf. C143-C160.

KOROTEV R. L., MORRIS R. V., and LAUER H. V. JR. ( 1993 ) Composition and maturity of the $60013 / 14$ core. Lunar Planet. Sci. $X X I V .821-822$ (abstr.).

KOVACH R. L. and WATKINS J. S. ( 1973) The velocity structure of the lunar crust. Moon 7, 63-75.

LiNDSTROM M. M. and LiNDSTROM D. J. ( 1986 ) Lunar granulites and their precursor anorthositic norites of the early lunar crust. Proc. Itoth Lunar Planet. Sci. Conf., D263-276.

MCKay D. S., Morris R. V.. Dungan M. A., Fruland R. M., and Fuhrman R. (1976) Comparative studies of grain size separates of 60009. Proc. 7th Lumar Sci. Conf. 295-313.

MCKaY D. S., DUngan M. A., MorRIS R. V., and Fruland R. M. ( 1977 ) Grain size, petrographic, and FMR studies of double core 60009/10: A study of soil evolution. Proc: 8th Luthar $S$ Cit. Conf.. 2929-2952.

MCKay D. S., Bogard D. D., Morris R. V., KoroteV R. L. JOHNSON P., and WENTWORTH S. J. (1986) Apollo 16 regolith breccias: Characterization and evidence for early formation in the mega-regolith. Proc. 16th Lunar Planet. Sci. Conf., D277-D303.

MC Kay D. S., Heiken G., Basu A., Blanford G., Simon S., Reedy R.. FrenCH B. M., and PAPIKE J. (1991) The lunar regolith. In Lunar Sourcebook (ed. G. HeIkEN et al.), Chap. 7, pp. 285-356. Cambridge Univ. Press.

MORRIS R. V. (1976) Surface exposure indices of lunar soils: A comparative FMR study. Proc. 7th Lunar Sci. Coni.. 315-335.

MORRIS R. V. (1978a) In situ reworking (gardening) of the lunar surface: Evidence from the Apollo cores. Proc. 9th Lunar Sci. Conf., $1801-1811$.

MORRIS R. V. (1978b) The surface exposure (maturity) of lunar soils: Some concepts and $I_{s} / \mathrm{FeO}$ compilation. Proc. 9th Lunar Sci. Conf., 2287-2297.

MORRIS R. V. and GOSE W. A., (1976) Ferromagnetic resonance and magnetic studies of cores 60009/60010 and 60003: Compositional and surface-exposure stratigraphy. Proc. 7 th Lunar Sci. Conf. 1-11.

MORRIS R. V., GoSE, W. A. and LaUer H. V. JR., (1978) Depositional and surface exposure history of the Shorty Crater core
74001 /2: FMR and magnetic studies. Proc. 9ih Lunar Planet. Sci. Conf., 2033-2048.

MORRIS R. V., LAUer H. V. JR., and Gose W. A. (1979) Characterization and depositional and evolutionary history of the Apollo 17 deep drill core. Proc. IOth Lunar Planet. Sci. Conf., 1141-1157.

MORRIS R. V., SCORE R., and DARDANO C. (1983) Handbook of Lunar Soils. JSC 19069. NASA Johnson Space Center.

MORRIS R. V., SEE T. H., and HORZ F. (1986) Composition of the Cayley Formation at Apollo 16 as inferred from impact melt splashes. Proc. 17th Lunar Planet. Sci. Conf., E21-E42.

MORRIS R. V., KoroteV R. L., and LAUER H. V. JR. (1989) Maturity and geochemistry of the Van Serg core $(79001 / 2)$ with implications for micrometeorite composition. Proc. 19th Lunar Planet. Sci. Conf., 269-284.

MUEHLBERGER W. R. (1981) C. Apollo 16 traverse planning and field procedures. In Geology of the Apollo 16 . Area, Central Lunar Highlands (ed. G. E. UlRICH et al.) USGS Prof. Paper 1048, pp. 10-20.

Muehlberger W. R., Hörz F., Sfyier J. R., and Ulrich G. E. (1980) Mission objectives for geological exploration of the Apollo 16 landing site. Proc. Conf. Lunar Highlands Crust (ed. J. J. PAPIKE and R. B. MerriLL), pp. (-49. Lunar Planet. Inst.

Rambaldi E. R. (1977) Trace element content of metals from Hand LL-group chondrites, Earth Planet. Sci. Lett. 36, 347-358.

RYDER G. and NORMAN M. D. (1979) (atalog of Pristine Nonmare Materials, Part 2. Anorthosites (revised). JSC 14603, NASA Johnson Space Center

SCHABER G. G. (1981) DI. Field geology of the Apollo 16 central region. In Geology of the Apollo 16 Area. Central Lumar Highlands (ed. G. E. UlRICH et al.); USGS Prof. Paper 1048, pp. 21-44.

SCHWARz C. (1991) Preliminary description of 60014 , top half of double drive tube 60014/60013. Lunar Planet. Sci. XXII, pp. 12011202 (abstr.)

SCHWARZ C. (1992) Preliminary description of 60013 , bottom half of double drive tube 60014/60013. Lunar Planet. Sci. XXIII, 12491250, (abstr.).

Spudis P. D. (1984) Apollo 16 site geology and impact melts: Implications for the geologic history of the lunar highlands. Proc. 15th Lunar Planet. Sci. Conf., C95-C107.

StOFfler D., OSTERTaG R., Reimold W. U., Borchardt R.. MALLEY J., and REHFELDT A. (1981) Distribution and provenance of lunar highland rock types at North Ray Crater, Apollo 16. Proc. 12th Lumar Planet. Sci. Conf. Part B. 185-207.

Stöfler D., Bischoff A., Borchardt R., Burghele A., Deutsch A., Jessberger E. K., OStertag R., Palme H., SPETTEL B., REIMOLD W. U., WACKER K., and WÄNKE H. (1985) Composition and evolution of the lunar crust in the Descartes Highlands, Apollo 16. Proc. 14th Lunar Planet. Sci. Comf.. C449C505.

SUTTON R. L. (1980) L1. Documentation of samples. In Geology of the Apollo 16 Area, Central Lunar Highlands (ed. G. E. UlRICH et al.); USGS Prof. Paper 1048, pp. 231-525.

Vaniman D. T., Lellis S. F., Papike J. J., and Cameron K. L. (1976) The Apollo 16 drill core: Modal petrology and characterization of the mineral and lithic component. Proc. 7th Lunar Sci. Cont. 199-239.

Wänke H., Palme H., Baddenhausen H., Dreibus G., Jagoutz E., Kruse H., Palme C. SPETtel B. Teschke F., and Thacker R. (1975) New data on the chemistry of lunar samples: primary matter in the lunar highlands and the bulk composition of the moon. Proc. Gih Lunar Sci. Conf., 1313-1340.

WARREN P. H. (1990) Lunar anorthosites and the magma-ocean plagioclase-flotation hypothesis: Importance of $\mathrm{FeO}$ enrichment in the parent magma. Amer. Mineral. 75, 46-58.

WILHELMS D. E. (1987) Lower Imbrium series. In The Geologic History of the Moon. Chap. 10: USGS Prof. Paper 1348, pp. 195226. 